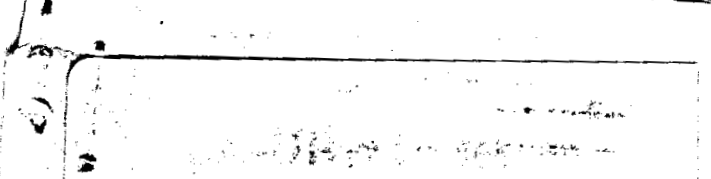

LA-UR- $-84-2564$

DE84 016475
NOTiCE

PORTIONS OF THIS REPORT ARE ILLEGIBLE: $N$ has been reproduced from the best available copy to permit the broadest possible avaitability.

Los Alamos National Laboratory is Operated by the Unweraty of Caffornia for the United States Department of Energy under contract W-7405-ENG-36.

$$
\text { CONF-840572- - } 4
$$

TITLE: DEEP DRILLING TECHNOLOGY FOR HOT CRYSTALLINE ROCK

AUTHOR(S): John C. Rowley, ESS-1

SUBMITED TO: International Symposium on Observation of the Continental Crust Through Drilling, May 20-25, 1984, Tarrytown, NY

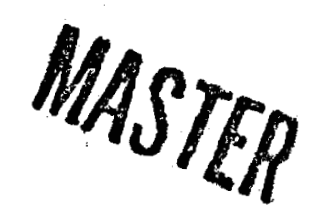




\section{DISCLAIMER}

This report was prepared as an account of work sponsored by an agency of the United States Government. Neither the United States Government nor any agency Thereof, nor any of their employees, makes any warranty, express or implied, or assumes any legal liability or responsibility for the accuracy, completeness, or usefulness of any information, apparatus, product, or process disclosed, or represents that its use would not infringe privately owned rights. Reference herein to any specific commercial product, process, or service by trade name, trademark, manufacturer, or otherwise does not necessarily constitute or imply its endorsement, recommendation, or favoring by the United States Government or any agency thereof. The views and opinions of authors expressed herein do not necessarily state or reflect those of the United States Government or any agency thereof. 


\section{DISCLAIMER}

Portions of this document may be illegible in electronic image products. Images are produced from the best available original document. 


\title{
DEEP DRILLING TECHNOLOGY FOR HOT CRYSTALLINE ROCK
}

\author{
by \\ John C. Rowley \\ Earth and Space Sciences Division, MS D462 \\ Los Al amos National Laboratory \\ Los Alamos, NM 87545
}

Manuscript intended as post-conference paper for inclusion in a special volume published by Columbia University Press as a proceedings for the:

\section{International Symposium on Observation of the Continental Crust}

Through Drilling

May 20-25, 1984, Tarrytown, New York

"No man's knowledge here can go beyond his experience" .... John Locke 
OUTLINE

Abstract

1. Introduction

1.1 Drill Site Location

1.2 Geologic Section

2. Hot Dry Rock (HDR) Project

3. HDR Experience Relevant to Scientific Drilling in the Continental Crust

3.1 Core Bits

3.2 Rock Bits

3.3 Bottom-Hole Assembiy (BHA) and Drill String

3.4 Driliing Fluid System

3.5 Casing Design

3.6 Fishing

3.7 Cost Estimates

4. Recommended Drilling Technology Improvements

4.1 Drill Pipe and Bottom-Hole Assemblies (BHA)

4.2 Coring Systems

4.3 Circulating Fuids

4.4 Fishing

4.5 Special Tools and Equipment

5. Discusston and Conclusions

Acknowledgments

References 
Abstract

The development of Hot Dry Rock (HDR) geothermal systems at the Fenton Hill, New Mexico site has required the drilling of four deep boreholes into hot, Precambrian granitic and metamorphic rocks. Themal gradient holes, four observation wells $200 \mathrm{~m}(600 \mathrm{ft})$ deep, and an exploration core hole $800 \mathrm{~m}$ $(2400 \mathrm{ft})$ deep guided the siting of the four deep boreholes. Results derived from the exploration core hole, GT-1 (Granite Test No. 1), were especially important in providing core from the granitic rock, and establishing the conductive themal gradient and heat flow for the granitic basement rocks. Essential stratigraphic data and lost drilling-fluid zones were identified for the volcanic and sedimentary rocks above the contact with the crystalline basement. Using this information drilling strategies and well designs were then devised for the planning of the deeper wells.

The four deep wells were drilled in pairs, the shallowest were planned and drilled to depths of $3 \mathrm{~km}$ in 1975 at a bottom-hole temperature of nearly $200^{\circ} \mathrm{C}$. These boreholes were followed by a pair of wells, completed in 1981, the deepest of which penetrated the Precambrian basement to a vertical depth of $4.39 \mathrm{~km}$ at a temperature of $320^{\circ} \mathrm{C}$. The drilling experience and developments will be of especially significant value in the planning of future drilling for the Themal Regimes portion of a Continental scientific Drilling Program (CSDP). Reviews of problems and solutions in the areas of circulating fluids, cuttings removal, bit selection and rate-of-penetration, casing design and cementing, wellbore directional control, and costs form a framework for that project planning. The influences of high temperatures, hardware limitations, hard and abrasive formations, equipment fatigue, and remedial operations (fishing) must be considered and understood to ensure the achievement of desired scientific goals. Successful completion of the four deep boreholes at 
the Fenton HIII HDR geothermal development site has produced hardware, technology, techniques, and provides practical examples and recommendations that can aid with the effective planning and conduct of future deep scientific drilling campaigns in the continental crust.

\section{Introduction}

This paper recounts the experience of deep drilling into hot crystalline rock by the Fenton Hill HDR project (Fig. 1) to fllustrate that such operations for scientific purposes are indeed possible. The discussion is intended to provide general guidance for project planning for future scientific drilling operations. The discussion also supports the thes is that experience from past ambitious drilling projects can aid in the design of the strategy of drilling and coring programs and help reduce costs and risks of such efforts in order to maximize the likelihood of success and scientific yield. Drilling hardware, operations, problems, and costs are described to give information to those interested in future deep, scientific drilling projects in the continental cause. The focus is on deep $(>3 \mathrm{~km})$ large diameter $[31.1 \mathrm{~cm}(12-1 / 2$ in.) to $22.2 \mathrm{~cm}(8-3 / 4 \mathrm{in.})]$ boreholes with spot coring of selected sections. The experience related here is in contrast to the relatively shallow, small diameter, continuous scientific coring operations such as those conducted to a depth of about $2 \mathrm{~km}$ by the Iceland Research Drilling Project, Fridleifsson, et al. (1982).

The high formation temperatures and very hard, often fractured, abrasive rocks penetrated at Fenton Hill are potentially to be encountered in the deeper portions of deep $(\sim 10 \mathrm{~km})$ boreholes in areas of typical or average geothermal gradients $\left(\mathrm{e.g} ., 25^{\circ} \mathrm{C} / \mathrm{km}\right)$, but especially in future projects planned to perform deep sampling into geothermal anomalies. These types of projects 
have been discussed as part of the "Themal Regimes" effort of the Continental Scientific Drilling Program (CSDP). Potential sites include the Valles Caldera, NM, Long Valley, CA, Yellowstone National Park, WY, and the Salton Sea, CA. Details of themal regime drilling objectives are recorded in the National Research Council, "Continental Scientific Drilling Program" (1979) and Goff and Waters (1980). Drilling, coring, borehole measurements, and sampling for scientific purposes in such hostile enviroments can be unexpectedly costly unless detalled planning and supervision of the drilling and coring operations by those experienced in similar operations is carefully performed.

Projects contemplating core and fluid sampling operations under these more severe conditions, especially higher temperature, will benefit from the technology improvements outlined here. The special coring hardware and drilling procedures successfully developed for the Deep Sea Drilling Project and summarized by Larson, et al., (1981) for deep ocean sediment sampling are fllustrative of those developments proposed here. The value of specially designed drilling equipment and procedures specifically for such scientific drilling projects cannot be overemphasized. The high-temperature rated, high-performance turbodrills designed and fielded for the HDR geothermal project (Neudecker and Rowley, 1982) are an example of the type of advanced technology development potentially required for successfur achievement of directional control of deep crustal boreholes. A second example, of wider interest to CSDP, is the hybrid core bit that was needed to achieve adequate core quality, reliability, and recovery in the deep crystalline rock at Fenton Hill (Pettitt et al., 1980). Finally, it should be noted that most drilling technology advances and case histories of potential interest to the scientific community are reported in the engineering ifterature and are usually familiar 
only to a very small and speclalized segment of the drilling and related industries. Thus, J. oliver (1982) quite correctly stresses the avallability of rig capability to perhaps $15 \mathrm{~km}(50,000 \mathrm{ft})$ depths. It is likely that harder rocks, scientific coring and sampling requirements, and high temperatures in drilling case of potential themal regime targets will necessitate significant shifts in drilling strategy away from that used in the petroleum industry procedures, which primarily focus on optimum penetration rate for commercial exploration and development. In addition, new technological developments away from the main stream of commercial drilling activity are difficult to transfer within the petroleum industry [Knight (1983)]. Knowledgeable and experienced personnel will play a most important role in the appropriate planning, supervising and on-line problem solving necessary to successfuliy conduct and field CSDP deep sampling projects. Costs can escalate rapidiy and projects may fail if effective planning and experienced supervision are neglected.

\subsection{Drill Site Location}

The Fenton Hill site is located in Sandoval County, New Mexico, approximately $32 \mathrm{~km}$ west of the Los Alamos National Laboratory (Fig. 1). Fenton Hill is in the Jemez Mountains (Fig. 2) and lies about $1 \mathrm{~km}$ outside the western topographic rim of the Valles Caldera in a region termed the Jemez Plateau. Laughlin (1981), and Laughlin et al. (1983) review the selection and the regional setting of the site. The brief summary here from Laughiin, et al. (1983) is intended as background for the drilling technology discussions that follow:

"The Jemez Mountains lie on the boundary between the colorado Plateau and the Rio Grande rift in north-central New Mexico. 
Volcanism occurred over the interval from roughiy 10 to $0.1 \mathrm{~m} . \mathrm{y}$. ago (Bailey et al., 1969) with major caldera collapses occurring at 1.4 and 1.1 m.y. ago to form the Toledo and Valles calderas. Rhyolite domes were extruded along ring faults of the Valles Caldera and they surround a large resurgent structural dome, Redondo Peak. The Redondo Peak area, which is highly faulted, is the site of a conventional (hydrothermal) geothermal prospect currently under investigation by Union Geothermal Company of New Mexico.

The plateaus that surround the Valles and Toledo calderas are capped by ash-flow sheets of Bandelier Tuff erupted during formation of the two calderas. Beneath the tuff in descending order are older volcanic rocks of the Jemez Mountains (Tschicoma and Paliza Canyon Formations), the Miocene Abiquiu Formation (Abiquiu Tuff of Smith, 1938), the Permian Abo Fomation (red beds), the Carboniferous Magdalena Group (mainly 1imestone), and Precambrian metamorphic and igneous rocks. The Precambrian surface lies at a depth of about 730 $\mathrm{m}$ at Fenton Hil1. Precambrian rocks are exposed at the surface a few kilometers south and west of Fenton Hill.

The Valles Caldera region and associated subjacent magma reservoirs provide an ideal setting for development of both hydrothermal and HDR [geothermal] systems. Only the presence or absence of secondary permeability distinguishes these two systems.

During early stages in the selection of the Fenton Hill site, eleven holes were drilled to determine the heat flow around the periphery of the Valles Caldera [Potter, 1973; Reiter et al., 1976]. The four deepest holes, which reached depths of 152 to $229 \mathrm{~m}$ and so are believed to yield the most reliable data, indicate heat flow 
values of 92 to $247 \mathrm{~mW} / \mathrm{m}^{2}$. The drill hole yielding the $92 \mathrm{~mW} / \mathrm{m}^{2}$ value was radially farther from the caldera, and probably sampled the regional heat flow."

\subsection{Geologic Section}

The locations of the shallow heat flow holes are shown in Fig. 2 . Geologic features of interest to drilling technology are sumarized in the stratigraphic section of Fig. 3 based upon results from subsequent deep drilling of boreholes, designated as GT-1, GT-2, EE-1, EE-2, and EE-3 in Fig. 1.

The geologic section at Fenton Hill consists of approximately $152 \mathrm{~m}$ (500 $\mathrm{ft}$ ) of welded volcanic tuff overlying $244 \mathrm{~m}(800 \mathrm{ft})$ of Permian red-beds (shales and sandstones), $335 \mathrm{~m}(1100 \mathrm{ft})$ of Pennsylvanian limestone, and below $732 \mathrm{~m}$ (2400 ft) Precambrian crystalline basement of extremely low permeability and porosity to $4.5 \mathrm{~km}(14,000 \mathrm{ft})$. The 1ithology represented in Fig. 3 was established by spot cores and cuttings, and generally without the benefit of geophysical logging in the deeper hotter sections. The temperature at the top of the Precambrian formations is $100^{\circ} \mathrm{C}\left(212^{\circ} \mathrm{F}\right)$, and the geothermal conductive gradient in this crystalline rock increases from $55^{\circ} \mathrm{C} / \mathrm{km}\left(30^{\circ} \mathrm{F} / 1000 \mathrm{ft}\right)$ to $89^{\circ} \mathrm{C} / \mathrm{km}\left(49^{\circ} \mathrm{F} / 1000 \mathrm{ft}\right)$ at $4.7 \mathrm{~km}(15,000 \mathrm{ft})$ depth $(\mathrm{Fig} .3)$. The temperature at the bottom of the deepest borehole $(E E-2)$ is $320^{\circ} \mathrm{C}\left(608^{\circ} \mathrm{F}\right)$.

The Permian red beds and the Pennsylvanian clays, shales, and limestones are sensitive to a fresh water based drilling fluid and contain several highly permeable zones that can cause lost circulation of drilling fluid. Several units in the Permian and Pennsylvanian formations in this section will also swell and become unstable causing sloughing of the wellbore (E. B. Nuckols, et a1., 1981). In addition, a cavernous zone in the Pennsylvanian limestone just above the crystalline basement rock at about $800 \mathrm{~m}(2400 \mathrm{ft})$ caused many 
extremely difficult drilling and casing problems related primarily to severe 10st circulation (Laughlin, et al., 1983).

The Precambrian crystalline basement has high intact compressive strengths, low pemeablity and is very abrasive. Much of it is gneiss with no discernible large-scale horizontal bedding. Several large intervals of granodiorite were encountered within the gneiss, and a number of narrow fractured zones that contained chlorite, pyrite, and considerable amounts of calcite. Much chemical alteration has occurred in these zones. They evidentiy are shear zones or locally shattered zones sealed or mineralized by the forceful late injection of fluids and volatiles into the host rock (Laughin et al., 1983). Variations in drilling performance and unexpected directional-drilling problems further indicated the presence of faults or altered zones in the wellbores.

Drilling the first slim (small diameter) core hole, GT-1, was an essential step in developing the scientific and engineering aspects of the site exploration strategy. The GT-1 borehole also served to delineate the potential drilling problems and provided a means to forecast for the larger diameter holes to be drilled through the section above the Precambrian rocks. The GT-1 corehole also discovered a shallow water-bearing unit used to supply drilling fluid for the later wells. Analysis of the crystalline rock core from the bottom of GT-1 established an initial baseline for the drilling properties of this unit. Such a slim diameter, shallow, core hole should be considered as an essential element of a deep CSDP hole, especially in a frontier area where no previous drilling records are available. The effort could usually be justified on the basis of the drilling-related lithologic data alone. 


\section{The Hot Dry Rock (HDR) Project}

Natural geothemal reservoirs can form where water has contacted rocks heated by shallow heat sources within the crust. In a few places, large circulating convection systems exist within porous or fractured reservoirs. These natural hydrothermal systems, often capped by an impervious layer, are characterized by high heat flux at the surface and are sometimes associated with leakage of fluids forming hot springs, geysers, and fumaroles. These natural hydrothermal reservofrs are rare, but may be excellent energy resources when properly exploited. Worldwide development of such high-grade hydrothermal reservoirs, greater than $180^{\circ} \mathrm{C}$ at depth, is at an installed electrical capacity of about $3200 \mathrm{MW}(e)$ (DiPippo, 1983) in 13 nations, from about 3000 drilled production wells. Exploration activities have located 147 hydrothermal reservoirs located in 43 countries. The current worldwide growth rate of installed geothemal generating capacity is approximately $15 \%$ per year.

Pursuit of research and development projects for innovative geothermal energy extraction systems has been motivated by the recognition that many conventional hydrothemal exploration and development wells do not produce fluids. Furthemore, the ratio of dry to productive wells in hydrothemal exploration averages somewhat greater than 3 to 1. The majority of the dry holes are hot, but penetrate rocks that lack sufficient fluids and natural permeability. Such hot, dry holes can be excellent prospects for stimulation, (Campbe11, et al., 1981) or for possible development as hot dry rock energy extraction reservoir systems. The latent energy contained in the HDR resource is imense, and its successfur development offers one promising alternative to supply a part of the world's increasing energy demands. Several HDR geothemal projects have been initiated around the world, with those in the 
United States, England, Germany, France, and Japan being the most advariced (Heiken and Goff, 1983).

Production of heat energy by the HDR technique involves creation of in situ permeability in hot rock formations by hydraulic fracturing followed by injection and circuiation of water. A two-well HDR reservoir system (GT-2 and EE-1), was created in the hot crystalline rock at Fenton Hill. Water was circulated and heat energy extracted to demonstrate the basic feasibility of the concept.

The HDR project was initiated at the Fenton Hill experimental site in 1974. The first two deep boreholes (GT-2 and EE-1, see Fig. 4 and Table 1) were drilled to about $3 \mathrm{~km}(10,000 \mathrm{ft})$ depth, at a bottom hole temperature of about $200^{\circ} \mathrm{C}\left(400^{\circ} \mathrm{F}\right)$. This well pair was fractured in $1975-1977$, to create the first reservoir. Results of extensive circulation and heat extraction experiments during 1978-1980 (Dash, et al., 1983) produced power at a 3 to 5 MW (themal) level for about one year and motivated the drilling of the deeper well pair, EE-2 and EE-3, in an attempt to develop a larger and hotter HDR geothermal reservoir.

This paper concentrates on the drilling experience from EE-2 and EE-3. These wellbores are inclined at $35^{\circ}$ from the vertical and configured so that parallel fractures could be made between the wellbores to create a HDR general reservoir (Fig. 5). The drilling of EE-2 and EE-3 was finished in August 1981 (Heimick, et a1., 1982 and Rowley and Carden, 1982). The boreholes were drilled with open hole reservoir sections at $22.2 \mathrm{~cm}(8-3 / 4-i n$.$) drilled$ diameters. The EE-2 injection well was drilled to a measured depth of $4.66 \mathrm{~km}$ $(15,298 \mathrm{ft})$ and had a bottom hole static temperature of $320^{\circ} \mathrm{C}\left(608^{\circ} \mathrm{F}\right) . \mathrm{EE}-3$, the production well, was drilled to a measured depth of $4.25 \mathrm{~km}(13,933 \mathrm{ft})$ 
and had a bottom hole temperature of $280^{\circ} \mathrm{C}\left(580^{\circ} \mathrm{F}\right)$. High-precision directional drilling was used to position EE-3 at $370 \pm 15 \mathrm{~m}(1200 \pm 50 \mathrm{ft})$ above EE-2 and within lateral location tolerances of $\pm 30 \mathrm{~m}( \pm 100 \mathrm{ft})$. This was done to maximize the possibilities for connection during post-drilling fracturing operations. Figure 6 depicts the directionally drilled wellbore trajectories for the EE-2/EE-3 well pair, and Fig. 7 summarizes the drilling histories for these two boreholes.

\section{HDR Experience Relevant to Scientific Drilling in the Continental Crust}

Scientific objectives of a deep scientific hole in the continental crust should be considered as early as possible to allow time for the development of equipment and drilling procedures that are specifically designed for the anticipated downhole conditions. Fenton Hill experience indicates that three principals should dominate this development phase:

- Do not assume that the drilling industry or another project has already developed a solution to a specific problem.

- Do seek multiple and alternative solutions with in-depth backup. Duplication of potential solutions will considerably reduce risk.

- Do expect special problems caused by high temperature. E 1 e $v$ a $t$ ed temperature performance for conventional drilling equipment and related services generally are 1 imited to $150^{\circ} \mathrm{C}$, but service to $200^{\circ} \mathrm{C}$ can be obtained in a few instances.

\subsection{Core Bits}

Coring technology and hardware is an area of special importance to CSDP projects and fllustrates the above principals very well. The original drilling plan for the first deep borehole, granite test No. 2, GT-2, in the crystalline rock at Fenton Hill called for continuous coring using Deep Sea 
Drilling Program (DSDP) core bit. The DSDP had succeeded in developing a successful rotary coring technology (S. Larson, et a1., 1981) for the sea floor sediments. The variety of coring tools that resulted were designed to obtain quality cores from the unique conditions and lithologies represented by the deep sea sediments. These tools include: (1) a piston corer for unconsolidated near sea bed surface, oozes and sediments, (2) a rotary driven, extended retractable core barrel for layered sections of highly variable hardness, and (3) a wireline deployed core barrel, coupled to a rotary driven four roller cone bit with tungsten carbide insert (TCI) cutting structure (Fig. 8). This core bit was designed to provide very long bit life through imposition of low loads on the roller cone bearings and long cutting structure life for both the core triming and drilling functions. These design features resulted in long bit life and therefore long intervals could be cored without tripping the bit, and provided high quality core. The annulus of the borehole drilled by this bit might be viewed as excessive with $25.1 \mathrm{~cm}\left(9-7 / 8-i \mathrm{n}_{\text {. }}\right)$ outer bit diameter needed to cut a $7 \mathrm{~cm}\left(2-7 / 8-i n_{\text {.) }}\right.$ diameter core. However, this bit design provided a very effective solution and a single bit could often be used to core the entire sedimentary section before it was dulled by a short penetration into the basalt basement below. Initial trials at Fenton Hi11, however, showed rather poor core recovery, slow penetration rates, and short bit life for the DSDP four-cone core bit. The primary causes were the hardness and extreme abrasiveness of the crystalline rock which rapidiy wore the core-triming TCI buttons. This caused the core diameter to gradually increase and to jam in the core catcher at the entrance of the core barrel. This jamming resulted in breakage of the core into 5-10 cm pieces, which were ground and abraded into near-spheres. Also, the TCI buttons on the roller cones that preform well in sea bed sediments, wore rapidly in the deep GT-2 
borehole. A solution to the core problem was sought using conventional diamond core bits, but recovery was often very poor (Table II). Finally, during the GT-2 drilling a solution was devised by a bit manufacturer who used a hybrid four roller cone and drag bit (fig. 9). The drag cutters were fashioned from polycrystalline diamond compact (PDC) cutting elements (Herrick, 1978). The core trimming was thereafter successful because of the Tow wear rate of these PDC drag cutters. Good core recovery and reasonable penetration rates of approximately $0.6 \mathrm{~m} / \mathrm{h}(2.0 \mathrm{ft} / \mathrm{h})$ were achieved.

Although this hybrid core bit was an adequate solution for the HDR project, which only required spot coring through crystalline rock at the 3 to $5 \mathrm{~km}$ depth interval, it seems clear that improvements in core bits and coring systems will be needed if deep, extensive or continuous coring of crystalline rocks are required for CSDP projects. It is judged that, even when optimized, a limit on bit life, penetration rate, and core quality will be reached for this type of hybrid core bit if a rotary drive is used at great depths.

A suggested development approach in coring technology research to solve this problem would involve use of a hollow shaft turbodrill such as that initialiy proposed by the Moho project for coring of sea floor basement rocks. Section 4, Fig. 16, indicates a conceptual design for such a coring system. The hollow shaft turbodrill would allow wireline core barrel retrieval. The core bit and core trimer should be developed based on the same philosophy as used for the DSDP tool designs. Long bit life can be enhanced through designs that use multiple cones (for low bearing loads) that are combined with drag cutters, and include heavy gauge and cutting structure wear protection. Optimizations to increase bit life, and thereby reduce tripping of the drill string, and improve core quality should dominate the development. The turbodrill would provide the high bit torque necessary to drive the PDC drag 
cutters. A higher rotating speed of the turbodrill relative to conventional rotary drives will enhance penetration rate and core quality through better bit dynamics, and improved bottom hole and drill string mechanics. In addition, the fatigue life of the drill string will be much longer, a distinct advantage when long cored intervals are planned. Another design feature to be considered is to allow the opportunity to replace or redress the core cutters with each core barrel run.

Turbodrill technology as applied to deep drilling operations in crystaline rocks was furthered by the HDR project when several deep directional drilling operations were conducted below $3 \mathrm{~km}$ and at temperatures exceeding $260^{\circ} \mathrm{C}\left(500^{\circ} \mathrm{F}\right)$. The successful develoment and use of such a high-temperature rated, high-torque, low rotational speed turbodrill (Rowley and Neudecker, 1982) could form the basis for design and development of hollow shaft turbodrills for CSDP coring application. These high-temperature rated turbodrills could uniquely be used for hole straightening, sidetracking, and directional drilling operations for CSDP projects; especialiy in deep hot boreholes in the harder crystalline rocks.

Rezanov (1981) describes deep scientific drilling in the soviet Union. From a literature study, and a visit to one deep drill site (Rowley and Watkins, 1977), it appears that the deeper geologic and stratigraphic studies in the Soviet Union rely heavily on cuttings, and that a deep coring technology has not yet been developed. A core bit with $21.4 \mathrm{~cm}\left(8-1 / 2-\mathrm{in}_{\text {. }}\right)$ outer diameter and $5.0 \mathrm{~cm}\left(2-\mathrm{in}_{.}\right)$core diameter is mentioned, but apparently used only for the shallower parts of the boreholes. Ioanesyan and others (1981) discuss a hollow shaft Soviet turbodrill used with high pressure drag bits, but no mention was made of use with coring tools. Deep continuous coring is discussed as a needed and desirable goal. These very deep (greater 
than 5 to $7 \mathrm{~km}$ ) scientific boreholes in the Soviet Union are being drilled by both rotary and turbodrill but most of the Soviet ofl and gas exploration and production drilling is accomplished nearly exclusively with turbodrills. Indeed, the Soviet petroleum industry personnel indicated that the deep drilling program was looked upon by them as a drilling technology development effort, and was directed toward the future when deeper petroleum production drilling would be more heavtly dependent on drflling in deeper, harder sedimentary rocks. It is certainly true, as experience with the deep HDR boreholes has demonstrated, that the high temperatures, high dynamic forces and fatigue stresses imposed on all downhole hardware, represent a very good test bed for finding weaknesses in drilling hardware, and for developing improved drilling hardware and techniques.

The Soviets also report:

- Development of a high torque, low rotational speed turbodrill suitable for crystalline rock drilling.

- That the $21.4 \mathrm{~cm}(8-1 / 2-i n$.$) roller cone bit size is optimum for bit$ ilfe and penetration rate in crystalifine rock.

- Difficulty in stabilizing turbodrill assemblies to maintain a straight hole.

These technological developments and observations by the Soviets for deep drilling are in accord with Fenton Hill experience. The significance of the possibility of long, deep, open-hole sections has many practical advantages for the planning and drilling aspects of DSDP projects, and especially for the potential scientific yield. The use of a protective or sacrificial casing string (see section 3.5 below) is worth serious consideration. This approach could be very valuable if long open-hole sections are to be rotary drilled or cored because wear of permanent casing strings and drilling of the shallow 
larger diameter holes can be very costly and possibly present high risks. The Fenton Hill experience confirms the long-term stability of open hole crystalline rock sections. The EE-1 and GT-2 boreholes have remained stable since 1975 from about $800 \mathrm{~m}$ to about $3 \mathrm{~km}$. Al so the EE-2 and EE-3 wellbores are open hole below the production $23.5 \mathrm{~cm}(9-5 / 8-i n$.$) casing point with about 900$ $\mathrm{m}$ of open hole below as shown in Fig. 3.

\subsection{Rock Bits}

This section summarizes from the HDR project deep crystalline rock drilling experiences in bit perfomance and selection that should be considered in any deep CSDP drilling plan and represent areas where serious and costly drilling problems could arise. Technical reports by Helmick et al. (1982), and Rowley and Carden (1982) give details.

The drilling of the deeper borehole pair EE-2/EE-3, summarized in Table 1, started with the spudding of the deeper borehole, EE-2, on April 3, 1979. This deeper well was drilled to a measured depth of $4.66 \mathrm{~km}(15,299 \mathrm{ft})$; a true vertical depth of $4,398 \mathrm{~m}(14,405 \mathrm{ft})$. The bottom open hole section was drilled to $22.2 \mathrm{~cm}(8-3 / 4-i \mathrm{n}$.$) diameter and inclined at 35^{\circ}$ from the vertical by directional drilling. The drilling time was 409 days. The second, shallower borehole, EE-3, was drilled to a measured depth of $4.25 \mathrm{~km}(13,933$ $\mathrm{ft})$; or a true vertical depth of $3,977 \mathrm{~m}(13,049 \mathrm{ft})$. EE-3 was drilled parallel to EE-2, as shown in Fig. 6, at a vertical depth of $370 \mathrm{~m}(1200 \mathrm{ft})$ above EE-2. EE-3 took 461 days to drill and complete. The drilling history vs. depth plots for the two boreholes are depicted in Fig. 7. This type of presentation is used throughout the drilling industry, and is a valuable way to summarize a drilling program or plan. As noted on the figure, both wells suffered major mechanical problems; EE-2 a collapsed intermediate (34.0-m, 
13-3/8-in.) casing string and EE-3 a severe drill string twist off and subsequent sidetracking operation.

The proper choice of drill bits is an important aspect of deep drilling in hard and abrasive crystalline rocks. Attention to early downhole bit evaluation and tests can optimize drill bit performance in a given lithology and avoid serious problems that otherwise could lead to lengthy remedial (fishing) operations. In this and the following sections it is assumed that initial deep CSOP projects will rely mainiy on rotary drilling with spot coring. The major consideration in bit selection in deep drilling is bit iife, with rate of penetration a secondary concern. This is because of the length of time required for round trips in deep holes greater than $3 \mathrm{~km}$.

Deep rotary drilling experience at Fenton $\mathrm{HIll}$ through over $7.6 \mathrm{~km}$ $(24,000 \mathrm{ft})$ of hot crystalline Precambrian rock has led to the following conclusions about drill bits:

(1) Bit life is the major factor in bit selection.

(2) Drilling rates in crystalline rock are uniform with depth, ranging roughly from 3 to $10 \mathrm{~m} / \mathrm{h}(10$ to $30 \mathrm{ft} / \mathrm{h})$.

(3) Drilling rate is primarily dependent upon bit cutting structure tooth configuration, and the force on the bit.

(4) Outer diameter gauge wear is the major bit problem.

(5) Sealed bit bearings are temperature 1imited; open bearing bits are required above about $200^{\circ} \mathrm{C}\left(400^{\circ} \mathrm{F}\right)$.

(6) Bit bearing life decreases with increasing temperature (i.e. depth).

(7) Only tungsten carbide insert (TCI) cutting structures were found effective for granite drilling.

Severe drilling conditions in hard crystalline rock will rapidly destroy poor quality rock bits. Even minor manufacturing defects lead to rapid bit 
fallures, which might not have occurred in less severe drilling conditions. For example, each new bit run must ream the previous hole diameter slightly because of hole taper due to gauge wear and hole diameter reduction from the previous bit run. Also, bits with weak leg structures readily "pinch," lose cutting structure teeth and cone tips, and torque-up quickly. Bit configurations based on blast hole type rock bits proved superior for reaming and drilling granitic and gneissic rocks.

Based upon these considerations, a special geothermal three-cone rock bit was used to great advantage and almost exclusively to drill the deep, $22.2 \mathrm{~cm}$ (8-3/4-in.) diameter sections of the EE-2 and EE-3 boreholes. This bit (see Fig. 10), is a nonsealed, air circuation, TCI bit. Several special design features that account for this superior performance are:

- harder and more abrasive resistant carbide TCI buttons were placed on the gauge row of the cones,

- hard facing for extra wear resistance was used on the leg skirt-tails,

o wear pad build-up and carbide inserts were included on the shanks of the legs,

o use of nonsealed bearings, and

- additional bearing clearances allowed for increased fluid circulation. These features increased bit life and reduced the number of trips to an extent that more than offset the modest (10\%) additional cost of the bit. These bits routinely provided bit runs greater than $60 \mathrm{~m}(200 \mathrm{ft})$, with average bit life greater than $90 \mathrm{~m}(300 \mathrm{ft})$. These long runs were made in the $35^{\circ}$ inclined sections of the holes where abrasive wear is especially severe. 


\subsection{Bottom Hole Assembiy (BHA) and Drill String}

The selections of a proper bottom hole assembly (BHA) and drill string are equally important for hard, abrasive crystalline rocks. The following factors are most important:

- A near-bit roller reamer (Fig. 12) should be placed immediately above the bit to aid with the undersize hole gauge problem caused by bit gauge wear. Blade type stabilizers (Fig. 11) wear far too rapidly to be used effectively.

- Drill string diameter and strength should be chosen with stress fatigue conditions as a primary guide. Generally, heavy wall drill strings with diameters equal to or greater than $12.5 \mathrm{~cm}(5 \mathrm{in.})$ will be necessary to accommodate the fatigue associated with extended hours of deep rotary drilling and coring. It should be noted that the larger inside diameters provided by these larger diameter drill strings will accommodate wireline core barrel operations offers potential for through-core-bit logging.

- A very thorough and rigorous drill string inspection program is also necessary.

- The bottom hole drilling configuration should be a well stabilized, strong pendulum-effect assembiy used with modest bit forces. This will provide for straight hole drilling; an extremely important objective in very hard fomations. Crooked holes contribute to drill string wear and stress cycle fatigue that result in downhole failures. Further, it is extremely difficult to straighten, or ream-out, a crooked hole in crystalline rocks; therefore it is far more important to drill a straight hole than to drill at a high penetration rate. 
- For very deep holes, greater than 5 to $7 \mathrm{~km}$ depths, a specially designed, tapered diameter drill string will be required.

The importance of high dynamic forces on BHA, fatigue life, and the influence of BHA design has recently been stressed by an analytical and experimental study reported by Darring (1983). These results relate especially to drilling or coring of harder rocks, and the problems avoiding resonance conditions in the BHA collars that are driven by bit rotational impact forces.

\subsection{Drilling fluid System}

Choice of suitable drilling fluid systems for deep CSDP boreholes will be dictated by many complex and possiby conflicting factors. The primary and essential function of the circulating fluid is to clean the drill cuttings from the hole. It may also be necessary to stabilize the upper formations, or those deeper zones, found to be water susceptible. This is accomplished by increases in fluid density and viscosity and additions of chemicals. The density and viscosity enhancements are usually accomplished by adding various clays (muds). It is often necessary to add chemicals to neutralize reactions between the formations and the fluid, in order to prevent excessive wash out of or squeezing into the hole. In the deeper, hotter portion of the boreholes cooling of bottom-hole hardware is an important consideration. Chemical additions for corrosion inhibition are necessary, especially in hot holes. These circulating fluid requirements may be in conflict with the scientific requirements to minimize the contamination of borehole, cores, cuttings, and formation fluid samples. To partially counter the contamination problem it is possible to consider the use of appropriate tracers injected into the circulating fluids to monitor the extent and nature of the invasions and contamination. 
Many crystalline rocks are water insensitive, and are mechanically stable and therefore a so-called "clear water" circulating fluid system can be considered. such a circulating fluid system is relatively clean, but it has a relatively low viscosity and lacks efficient carrying capacity for the cuttings. This leads to poor bottom hole cleaning of chips so that the cuttings are reground to a fine powder and results in inefficient drilling. Surface inspection of fine cuttings is more difficult and can reduce the scientific quality of this evaluation. The fine cuttings increase abrasive wear of downhole hardware. Higher fluid pumping rates, that is higher fluid velocities, and periodic sweeps with discrete slugs ("pills") of high viscosity mud can be used to clean the hole. A second major disadvantage of the clear water fluid system is that only slight lubricity of the wellbore is provided. That is, high friction between drillstring, bottom-hole assembly and the borehole wall can develop. Formations of low permeability cause little or no mud cake to form on the borehole walls and lubricity will be reduced further. Low lubricity leads to both high drag forces with increased risks of drill string failure (twistoffs), stuck drillstring, and increased abrasive wear of downhole hardware. A complex mud system will not always be a drilling advantage, or a clear water system may be dictated by the scientific goals. In that circumstance, lubricity agents must also be added; a selection will be based on the chemical contamination restrictions of the project. Most mud systems have temperature limits, and tend to degrade at high temperatures. In addition, if circulation is halted (for example to change a dulled bit) muds will harden in the hot wellbore sufficiently so that they must be drilled out. If fracture permeability is encountered mud loss can be very severe and, with temperature hardening the mud will plug deep into the fractures and possibly restrict desired fluid sampling from fracture zones. Fluid sensitive or 
highly permeable shallower zones, perhaps sedimentary or metamorphic rocks, might best be sampled with a separate small diameter (slim), shallow core hole, as outlined in section 3.5. This approach has the advantages of providing good core quality for these shallow zones, and the detailed stratigraphy needed to effectively plan the subsequent, deeper, much larger diameter, holes that can then be drilled with no core requirements and therefore with an optimum circulating fluid program that is designed to mitigate hole stability and lost circulating fluid problems.

\subsection{Casing Design}

A casing design for a deep CSDP. borehole will usually be quite different than that for a deep oil and gas well. This is due mainly to: (1) different rock types expected, (2) stable formation can be anticipated, and (3) 1arger diameter bits will be required to yield long bit life in the deeper, hard rock sections of the holes. One design option might be to consider an open hole method practiced by the Soviets. This element of the Soviet "uitra deep" drilling technology that might potentialiy be very important in future U.S. deeper boreholes is the procedure termed by the soviet drillers as the "advance open borehole drilling method." It is lllustrated in Fig. 12. The more usual casing design that involves cementing a sequence of progressively smaller casing diameters and drilling below with successively smaller bits, is replaced by a casing program that drills at an initial large diameter of 92.0 $\mathrm{cm}\left(36-1 / 4-i n_{.}\right)$with a cemented-in $72.0 \mathrm{~cm}(28-1 / 2-i n$.$) casing, Fig. 12(a). A$ $24.5 \mathrm{~cm}$ (9-5/8-in.) diameter protective, or sacrificial, casing string is run in but not cemented. Drilling with a turbodrili below this protective casing string proceeds with a 21.4 an $(8-1 / 2-1$..$)$ diameter bit and the hole remains in an open condition to a depth and for as long a duration as the borehole wall remains reasonably stable. When hole caving or sloughing occurs the 
drilling assembly is pulled from the hole and the protecting $24.5 \mathrm{~cm}$ (9-5/8-in.) casing string is retrieved. The hole is reamed to a larger diameter below the unstable zone, or to the bottom of the previous drilling. Typically a $39.4 \mathrm{~cm}\left(15-1 / 2-1 \mathrm{n}_{\text {.) }}\right.$ diameter drill bit (or reamer) size is used to open the hole diameter and clean out the borehole. Then a deep cemented-in casing of $32.5 \mathrm{~cm}(12-3 / 4-i n$.$) diameter is installed, Fig. 12(b). Drilling$ operations continue, Fig. 12(c), following the installation in the reamed and cased hole again of the protective or sacrificial $24.5 \mathrm{~cm}(9-5 / 8-i n$.$) casing$ that is not cemented in place. Drilling below proceeds with the $21.4 \mathrm{~cm}$ (8-1/2-in.) bit. The Soviet reports stress the obvious advantages of such a procedure of long open hole intervals for geophysical logging. Also they have reported heavy casing wear of the protective strings from just the tripping in and out of the very deep holes. This technique was first used in the Kola peninsula borehole (abbreviated as UD-3; Ultradeep No. 3) successfully to a $10,780 \mathrm{~m}(35,367 \mathrm{ft})$ depth in 1981 .

A second scheme is lllustrated in Fig. 13, a possible design for a thermal regime CSDP project. A sequence of successively deeper holes provides data for the casing design for the next deeper core hole, while likely assuring higher quality cores, logging, and sampling of the upper part of the section. This approach provides the opportunity to design a sufficiently durable and stable final casing program so that wear and collapse conditions can be projected and accounted for. The major wear will come from the many round trips into the deep holes and the long rotating hours caused by the slow penetration rates experienced in hard rocks for both coring and drilling. Uphole casing collapse can result from wear, poor cementing due to lost circulation zones, and exposure to high temperature fluids produced from deep formations. Geologic knowledge from the earlier shallower core holes and 
knowledgable drilling and casing designs can avoid or help mitigate these problems. A collapsed casing can require lengthy remedial operations (fishing) and repair, or in a worst case, the hole may be lost. This second example is in reality a brief discussion of a general strategy for CSDPthemal regimes deep drilling. First, it must be appreciated that there is a necessity to design the drilling, coring, and sampling program in response to the scientific requirements of a particular thermal regimes project. This is illustrated here by an example project that requires continuous coring through and below an active hydrothermal system to a depth of about $8 \mathrm{~km}$. This example strategy is intended to maximize the recovery and quality of core, provide appropriate flufd samples, and preserve open-hole sections for geophysical measurements. CSDP-themal regimes drilling and coring planning must focus on the specific site scientific goals and objectives of the particular CSDP project. These are expected to concentrate on coring and sampling. Therefore the drilling strategy to optimize the scientific yield will also be very site specific. The strategy proposed to achieve these goals suggests a sequence of progressively deeper and larger diameter core holes.

The sketches in Fig. 13 fllustrate one possible approach intended to optimize the scientific yield. It is assumed that the scientific objectives require essentially continuous core, fluid samples and open-hole logging. A three-stage, orfliting and coring program is proposed:

(1) Slim hole core to the top of the hydrothermal system, Fig. $13(a)$, shown at about $1 \mathrm{~km}$ depth.

(2) Use the 1ithology from this first stage to plan a second, larger diameter hole designed to core through the hydrothermal system, and below the depth reached by the first slim core hole. This second section is expected to be primarily in permeable fractured rock 
formations; problems of lost circulation of driliing fiuids, borehole instability, and high temperatures will dominate this stage. A dual string, gas lift core drilling system (Darring and Kelsey, 1981) is suggested, Fig. 13(b) as one method of minimizing lost circulation problems. A depth of $3 \mathrm{~km}$ is presumed to just penetrate into the unfractured crystalline formation below the active hydrothermal convection system.

(3) Drfll a third, larger diameter hole through the hydrothemal system. The knowledge from the first and second holes is used to design the upper portion of this third hole. It is a straight drilling section, with no coring. An extra heavy casing is set and cemented a few hundred meters into the crystalline rock. A second, protective, or sacrificial casing is set inside this primary casing string, Fig. $13(\mathrm{c})$. Coring below is assumed to be into completely unknown formations. The heavy casing program is suggested because core drilling to a depth of $8 \mathrm{~km}$ and perhaps temperature of $\mathrm{r} 500^{\circ} \mathrm{C}$ are anticipated. Very slow coring rate (many rotating hours) and the time needed for solution of downhole problems must be anticipated to ensure good recovery of high quality core. A $21.6 \mathrm{~cm}$ $(8-1 / 2-i n$.$) diameter bit is suggested for this deepest core hole to$ assure long bit ilfe.

All three holes would be sited in close proximity at the surface so that drilling surprises would be minimized.

This brief exposition lliustrates the types and range of drilling strategy, hole designs, and casing schemes that might be necessary to conduct a CSDP deep drilling project. Other CSDP projects will require different drilling and sampling strategies. However, it is probabiy always wise to 
consider an exploratory, slim core hole to 1.5 or $2 \mathrm{~km}$ depths as an initial step in any unknown or wildcat area.

\subsection{Fishing}

As a final topic from the experience gained from the Fenton Hill drilling, it is necessary to discuss the subject of problem solving operations in deep boreholes. These remedial operations are usualiy referred to as "fishing" in the drilling industry. The important consideration is that, next to avoiding problems, effective and efficient downhole problem solving is extremely important. Experienced personnel and the proper equipment and tools are the essential ingredients to successful removal of broken hardware from the borehole. It should be recognized that for the hot hole conditions to be encountered in themal regimes CSDP projects, many fishing tools are temperature limited, or have temperature degradable components. Examples are the often needed wireline conductor cables and high explosive charges used to unscrew (backoff) downhole threaded connections. One slight advantage can be cited for the very hard deeper formations anticipated in many CSDP projects, it is generally easier to fish objects (junk) from holes in the harder formations because there is less likelihood for the junk to become jammed or pushed out into the rocks, as is often the case in softer formations. Failure to remove (fish) junk from the hole can have significant impact on a drilling project because then the decision must be made whether to abandon the hole or to drill around the junk (sidetrack the hole) from above the unretrieved objects and thus bypass the junk in order to continue drilling. Sidetracking in crystalline rock has proven to be very difficult (Pettitt and Carden, 1981) and when completed, the crooked hole section produced introduces additional drillstring drag forces and increased stress levels. These hole conditions will add to the drilling risks in the deeper parts of the hole. Especially 
important is the additional fatigue induced during deep rotary drilling or coring.

Both EE-2 and EE-3 were problem wells, and plagued with lengthy fishing operations as shown on Fig. 7. EE-2 suffered a collapsed intenmediate casing string and $34.5 \%$ of the 409 drilling days were needed to clear the problem. The EE-3 borehole suffered fron a large number (26) of drillstring failures (twistoffs). One especially bad twistoff required sidetracking. These associated fishing and sidetracking problems occupied nearly $50 \%$ of the 461 drilling days.

\subsection{Drilling Costs}

The usual method of deriving detalled drilling cost estimates is to sum up all the individual cost element estimates of a specific detalled drilling plan and borehole design. For a hole in the 7 to $9 \mathrm{~km}$ depth range, this is a considerable task. Such a design, engineering optimization, and cost analysis effort might require one to two years of time, and this effort should be allowed for in any CSDP planning and scheduling process. A quick order-ofmagnitude cost estimate can be gained from historical data. An example of this type of data is shown in Fig. 14. Drilling costs are plotted on a log scale against well depth for intermediate diameter holes between $15.0 \mathrm{~cm}$ $\left(6-\mathrm{in}_{.}\right)$and $<30.5 \mathrm{~cm}\left(12-\mathrm{in}_{.}\right)$. These are cost data for geothemal production and expioration well drilling and are refered to 1979 dollars, with an escalation factor of about $17 \%$ per year used through 1981 . For reference and comparison the average cost trends for U.S. ofl and gas wells are also plotted, as are the costs of drilling the five Fenton Hill boreholes, adjusted to the value of 1979 dollars. As an important observation, the increased cost effects of hard, fractured rocks and higher temperatures experienced in geothermal and HOR driliing are evident, when compared to the oil and gas 
drilling experiences at the same depths. The cost depth trends are seen to be exponential with depth. Clearly scientific boreholes drilled to 9-10 km depths will be dear.

\section{Recormended Drilling Technology Improvements}

This discussion is an outline of needed drilling technology improvements, with special emphasis on solutions to problems associated with deep, high temperature drilling, coring and sampling in the continental crust. These needs are drawn from direct rig-floor, field experience attained during the Los ATamos HDR drilling operations and from interactions with drillers from Italy, France, England, the Federal Republic of Germany, Japan, and Canada, as well as many U.S. geothenal drilling operators. Experience was also gained through collaboration with the private sector to develop high temperature downhole drilling tools such as hydrautic drilling jars, core bits, shock absorbers, and turbodrills. In addition, involvement with development field trials and of advanced rock melting drilling systems (Rowley, 1974) provided a unique perspective on problems of high temperature drilling. Generally, these brief technology descriptions proceed fran the simpler components needing improvements to longer term, more complex hardware items. Discussions of advanced drilling methods or techniques that might be required for coring and sampling in deep formations at temperatures in excess of $600^{\circ} \mathrm{C}$ are not included.

This outiline of needed improvements is organized into five major categories for the purpose of focusing the presentation. The topics selected are drill pipe and bottom-hole assemblies, coring systems, circulating fluids, fishing, and special tools and instruments. 


\subsection{Drill Pipe and Bottom-Hole Assemblies (BHA)}

Pipe Dope - A special high-temperature thread lubricant (pipe dope) is needed when temperatures exceed $300^{\circ} \mathrm{C}$. Adequate lubrication must be provided to prevent galling, seisure, and tool joint (thread) make-up downhole. A positive seal must be maintained to prevent drilling fluid leaks and washouts. Suifur must be excluded from the lubricant because of associated corrosion problems. A two-component system appears to be required: (a) an anti-galling metallurgical treatment or coating on the threads, and (b) a high-temperature "grease" that is in turn, composed of two components; one that will assure proper flow characteristics at ambient temperatures and a high-temperature portion that will remain in place as a seal and lubricating film. An essential property of the thread dope or compound is that it must be capable of breakout (being unscrewed) after extended stress cycles at high temperatures.

Drill Collars and Drill Pipe Design - Special alloy collars with tailored dimensions, and connection designs will be needed. The inside diameter of the BHA and drillpipe should be selected to be at least $10 \mathrm{~cm}(4 \mathrm{in.}$ ) so that wireIine core barrels can be run and logging can be performed within the drill string. This will require special connection design to increase high temperature strength and fatigue 1ife." The alloy should be selected to provide enhanced high-temperature hardness (abrasion resistance), corrosion resistance, and extended fatigue 11fe. Development of a special orill pipe is recommended with a minimum $10 \mathrm{~cm}(4-i n$.$) inside diameter for the casing given$ above. It will be necessary to design special drill string for the extreme depths $(>5$ to $7 \mathrm{~km})$, with larger diameter and thicker walled sections located at the top of the hole. 
Drill Pipe and BHA Inspection Strategy \& Equipment - It is suggested that two drill pipe strings be used in the coring of very deep formations, i.e., greater than $5 \mathrm{~km}$. Avoidance of drill pipe failures in CSDP drilling projects is very important, and therefore frequent and detailed inspection will be necessary. One effective strategy is to inspect one string while the second is in use. A second element of an effective strategy should be to develop a special dedicated set of inspection equipment that will provide sensitive and high reliability detection of flaws and allow rejection of flawed sections (joints) of the drill string.

Drill Pipe Indentification System - A technique to uniquely and reliably identify each length (joint) of drill pipe is needed. The system should include rig floor identification reading scanners with on-line talley, drill string stress computations, and accumulated stress fatigue cycle evaluations. A schematic sketch of such system is presented in Fig. 15.

Heavy Weight Drill Pipe Joints - To improve BHA design and downhole drilling dynamics, and to reduce drag forces during rotary drilling and coring, a special set of heavy wall drill pipe joints should be provided to replace upper section of the drill collars in the BHA. Special alloy selection considerations should be simflar to those suggested above for drill strings and collars.

Hardbanding - Adequate high-temperature hardbanding methods should be developed to protect the drill pipe connections and collars from excessively high abrasive wear rates. This is especially important in crystalline rock:-

Float Values - Both rock bit drilling and coring operations in hightemperature boreholes require the use of reliable check valves in the BHA above the bit. Otherwise cuttings and well fluids are prone to backflow up inside the drill string and tend to plug the components of the bottom-hole 
assembiy. The problem is especially severe for wireline coring operations that tend to swab the drill pipe when the barrel is retrieved, and for use with downhole motors or other components that have tight clearances. Temperature upgrading of float valves is recommended.

Dual String Drill pipe System - Drilling and coring of active hydrothermal systems, with high permeability formations, usually involve severe lost drilling fluid circulation. Fractured rock units with extremely high permeabilities are commonplace and subhydrostatic conditions are often encountered. Solutions for these difficult conditions can sometimes be achieved by use of concentric, dual drill strings as indicated by Darring and Kelsey (1980). Design and avallability of such a dual string system that can be used to at least $3 \mathrm{~km}$ depths, with wireline core retrieval [10-cm $(4-\mathrm{in}$. I.D.] capablitity for the inner string, is recomended.

Reamers and Stabilizers - In hard, abrasive rock, driliing or coring bottom-hole assemblies (BHA) will require use of roller stabilizers in place of blade stabilizers that wear too rapidly. A near-bit, roller reamer should be run with all orflling and coring assemblies. Excessively rapid bit guage wear results in drilling of a tapered hole diameter. A tapered hole in hard rock can cause the BHA to become friction jammed in the hole. Extended reaming of the borehole with each new bit will be minimized by use of the near-bit reamer. Use of roller reamers is also recommended, because blade-type tools wear too rapidly and this loss of diameter can cause the BHA to lose directional control effectiveness. Drilling of a crooked hole can result, and this is an especially severe problem in hard rock.

Drill Bit Selection - In the drilling of hard, crystalline rock, bit selection should primarily emphasize bit 1ife. Development of sealed bearing, high-temperature bits would be an important and distinct improvement. Blast 
hole type bits, with heavy-section leg structures are suggested, to avoid leg bending and cone pinching. Heavy guage wear protection is essential to retard bit guage wear rates. Bit cutting structures must emphasize tungsten carbide insert (TCI) button selection that provides wear resistance on guage rows and high impact resistance for the insert cutters on the cones. Air cooled type bits, designed for high-temperature geothermal drilling, can be used to advantage with clear water or high-temperature mud fluid circulation systems. Bit selection should emphasize bit life for deep drilling in crystalline rock. Penetration rate is a secondary factor in bit selection for hard, crystalline rock. Rate details of the cutting structure design, for these rock types.

\subsection{Coring Systems}

Rotary Diamond Coring - Technology and equipment exists for slim hole coring to depths of 1.5 to $2.0 \mathrm{~km}$ depths. Efforts to develop and extend these techniques and equipment to beyond $3 \mathrm{~km}$ depths are recommended with emphasis on development of higher temperature diamond bit capabilities.

Downhole Motor Driven Systems - One drilling method for potential improvement of deep core quality and recovery is the use of a downhole motor to drive the core bit. For high temperature use this requires a turbodrill, a $40-m(120-f t)-10 n g$ core barrel in front of the downhole motor, and special core bits. Downhole motor drives will improve bottom-hole bit dynamics compared to rotary drive coring systems. In addition, drill pipe, stresses, fatigue, and wear will be significantiy reduced, and up-hole casing wear minimized.

Wireline Barre1, Downhole Motor Driven System - A recommended system conceptual design is sketched in Fig. 16. The system includes a 10-cm (4-in.) 0.D. wireline barrel, a hollow shaft (high-temperature) turbodrill, a combined multi-cone and polycrystalline diamond compact (PDC) bit, and a PDC 
core trimmer included on the retrievable barrel. Significantly extended bit runs can possibly be achieved with such a system. This concept is based directly on the original Mohole and the DSDP coring system ideas, designs, and experience.

Rotary Bit Improvements - Improvement of hybrid multi-cone plus PDC core bits will improve rotary core recovery and extend bit life. Efforts to improve this existing type of bit for specific rock types should accelerate the development of improved core bits for hard rocks. Coring effectiveness depends on long bit life, stable downhole bit dynamics, and effective core cutting and triming; features that are possible with hybrid core bits.

\subsection{Circulating Fluids}

Clear Water Systems - Scientific coring and drilling usually requires that wellbore fluids and formation contamination be minimized. This often requires use of a clear water circulating fluid. Driliing problems associated with this approach are poor cuttings removal and ineffective bottom-hole cleaning. Solutions to these problems with clear water circulation include use of circulation of discrete high viscosity mud pills, and use of high fluid flow velocities. An additional problem with a clear water system, is the absence of filter cake (solids from the mud) deposited on the borehole wall. This condition leads to high rates of abrasive wear of downhole hardware and extremely high torque and pull friction arag forces on the drill string. A Tubricity agent can be used to offset these latter conditions; however, an suitably inert and stable high-temperature additive does not yet exist.

Cuttings Removal - Removal of very fine cuttings from the orilling fluid is difficult, but important in scientific drilling or coring situations. The clear water systems are difficult to remove cuttings at the surface. Use of high viscosity pills as mentioned above are an aid to solving this problem, 
but more effective filter and centrifugal mud solids removal systems are needed.

Fluid Cooling - High temperature downhole conditions will usually require use of a surface fluid cooling system. A heat exchanger system with low circulating fluid aeration or oxygen entrainment is most desirable in order to reduce corrosion control problems.

Corrosion Control - A carefully designed corrosion control system is important. Minimization of exposure to air and suppression of oxygen entrainment are necessary. Consideration of use of a nitrite additive as an oxygen scavanger is recomended. A complete and effective fluid chemistry and corrosion monitoring system is essential.

Rig Pumps - It is necessary to provide for sufficient excess rig pump flow and pressure capacity to handle high flow and pressure requirements needed for extended cooling and problem solving demands that will arise in deep, hot themal regimes boreholes.

Lightened Fluids - Use of nitrogen gas, water mixture and use of nitrogen foams can be effective in fluid loss, corrosion and formation contamination problem situations. Lightened fiuid columns with good cuttings removal can be achieved with foams. Development and fabrication of diesel exhaust nitrogen gas production systems (Osgerby et al., 1981) is strongly recommended. Coring operations with such lightened fluids and nitrogen gas must be developed.

Higher Temperature Rated Muds - It can be expected that deep formations that are unstable due to interactions with water or high pressure conditions will be encountered in some CSDP thermal regime targets. An improved high temperature mud system will be needed to cope with these problems. Capability beyond the present sepiolite clay-based systems $\left(300^{\circ} \mathrm{C}\right)$ is required. 
Lost Circulation Control - Improved high temperature "additives" and placement tools for lost circulation materials (LCM) should be developed. Lost circulation zones can jeopordize coring. Systems designed specially to control circulation lost to fractures need to be developed.

\subsection{Fishing}

Fishing Tool Upgrade - Downhole problems can be expected in any deep, hot hole, and therefore an essential task of drilling and coring procedures is to solve these problems effectively and rapidly. This requires a review, and then deveiopment effort, to upgrade the temperature rating of the usual downhole tools required to conduct such "fishing" operations. Typical equipment upgrading needs are

- Drilling and fishing jars, hydrauliçally operated units are most desirable.

- Mills, especially the cutting structure.

- Back-off high explosive shots, especially high temperatures, detonators and wirelines.

- Seals for grapples and overshots.

- Impression blocks.

- Cut-off tools.

- Free-point detection tools.

These improvements are important because the downhole problems often preclude the use of fluid circulation for cooling that can help marginal or underrated tools function.

Experience - An essential element in any successful fishing operation is the selection and availability of experienced personnel. 


\subsection{Special Tools and Instruments}

Sand Line - The cables used to run various downhole tools in hot boreholes must have steel wire cores and be high temperature rated. Socket connections must be mechanical in design, because commonly used babbitt metals melt well below $300^{\circ} \mathrm{C}$.

Borehole Survey Instruments - Drilling of straight or deliberately deviated holes demands good single- and multi-shot survey instruments. Both magnetic (compass) and gyro instruments for higher temperature service are needed. Steering tools for directional drilling monitoring and control of directional corrections must be available for the more extreme temperatures anticipated in CSDP themal regimes projects. Crooked hole conditions are special hazards in the high-drag conditions encountered in boreholes in hard crystalline rock. Excessive crooked hole condions ("doglegs") can seldom be eliminated or cured by even extended reaming with stiff reaming assemblies.

Hole Caliper - Knowledge of borehole wall rugicity, is essential to many drilling, coring, casing, and downhole tool-running operations. As an example, a top priority need exists for a caliper run before any drill stem test or packer setting operations are attempted.

Drill Stem Tester - It is often very desirable to obtain a fluid sample during drilling or coring operations. If a wireline core system is employed, then sampler can be run within the drill pipe and, if contamination by drilling fluid is not considered to be a problem, a sample can be obtained by reversing flow into the sampler. However, if drilling fluid contamination is to be avoided, a drill stem tester (DST) as shown in Fig. 17 can be used. The packer seal to the wellbore wall need not resist large pressure differences, because it functions mainly as an isolation seal from the drilling fluids in the annulus. The packer is only to be used once so high temperature 
non-elastomeric materials and compression-type packer, activated upon set-down, can be considered. The drill stem tester is run oniy partialiy filled with (clean) water so suction draws the sample from the zone being tested. A reliable high-temperature mechanically opened valve and a flow check valve are required. The scheme shown in Fig. 17 includes a smaller diameter bottomhole drilled section, or rathole. Drilling this reduced section can enhance the wellbore surface finish for improved packer setting and sealing. Subsequent ream-out of the rat hole is possible, and spall, or hole sloughing, caused by the fluid sample withdrawal can be removed. Such a scheme also minimizes hole swabbing at retrieval of the DST system, and can alleviate packer washout during running into the borehole.

Packer Systems - Development of high temperature packer systems should be given a high priority. A variety of configurations, i.e., single set and straddle; both hydraulic and mechanical setting mechanisms; and inflatable and compression systems should be persued.

Cementing - Improved high temperature cements, cementing hardward and placement techniques are needed to assure adequate hole casing programs and to support many remedial operations; e.g., borehole sidetracking and hole stabilization. Reliable cement slurry formulations that are stable against adverse downhole chemistry, gases, and high temperatures are needed. The set-up and cured cement should be durable, of low permeability and retain strength. Improvements in placement hardware and procedures are also necessary.

Downhole Coring Monitoring - The requirements for high quality core and good recovery of scientific drilling projects dictate that the development of a downhole data-while-coring (DWC) system is warranted. Core quality and recovery are directly related to the control of the drilling parameters, and 
BHA and core bit dynamics. Therefore development of an instrumented, high temperature rated subassembly (collar) with appropriate drilling parameter and dynamic force and motion sensors is recomended. In addition, if a hollow shaft turbodrill, with wireline core barrel retrieval is developed, a sensor package can be included in the barrel, and the data telemetered on the cable. Because the drill string is not rotating in such a system the cable can be left latched onto the barrel and connected into the instrumentation during coring operations.

Logging While Drilling or Coring - A number of advantages would result from the develoment of a special drilling subassembly that contained an appropriate suite of geophysical measurements (logs) that could be monitored at the surface. Identification of 1ithologic changes could provide input for decisions on coring runs of scientifically significant intervals. The ability to review real time geophysical data and make spot coring decisions could ultimately result in more efficient coring procedures and operations than continuous coring or cuttings observations.

\section{Discussion and Conclusions}

The LoS Alamos Fenton Hill HDR drilling experience and several other deep, hot hole drilling profects have been used to provide this perspective on scientific drilling in the continental crust. The results from the two $2 \mathrm{~km}$ deep HDR wells in Cornwall, England; the three $3 \mathrm{~km}$ deep wells in British Columbia, Canada; the geothermal well at Puna in Hawail; the Italian geothermal drilling experfence, and the deep drilling in the Soviet Union have provided additional background information on drilling and coring in crystalline rock. Future CSDP thermal regimes projects can benefit from the drilling 
experience from geothemal production wells with bottom-hole static temperatures in the range of 300 to $400^{\circ} \mathrm{C}$. These wells are now drilled rather routinely. However, coring and geophysical logging in that enviroment are not well developed technologies.

The Soviet deep crystalline rock drilling experience, especially represented by the Kola peninsula borehole (abbreviated as UD-3) drilled successfully to a $10,780 \mathrm{~m}(35,367 \mathrm{ft})$ depth, supports several of the results and technology needs outlined above.

The Soviets report:

- Development of a high torque, low rotational speed turbodrill suitable for crystalline rock drilling.

- That the $21.4 \mathrm{~cm}(8-1 / 2-1 \mathrm{n}$.$) diameter roller cone, TCI cutting$ structure bit is optimum relative to bit life and penetration rate in crystalline rock.

o. Development of hollow shaft turbodrills.

- The desirability of continuous coring in scientific drilling projects.

- The general stability of long open hole sections in crystalline rock; and the advantages of open hole for both driling and geophysical logging.

Experience has accumulated in drilling technology, indicating that for downhole tool and special surface equipment development, several general principies should be observed:

(1) Always develop at least two prototypes of hardware.

(2) Laboratory and field tests and trials are necessary prior to deployment of equipment to a CSDP drill site.

(3) Avoid hardware and technology development efforts in scientific boreholes. 
(4) Develop and provide at least one (or more) backup procedure, approach or hardware solution to a drilling problem. Experience indicates that the best ideas and concepts may not apply downhole due to unanticipated borehole conditions. It is essential that more than one new hardware approach, source of a service, and method of solution be available. Competitive solutions are very important elements in obtaining satisfactory results downhole, and to devise effective solutions to drilling problems.

(5) The CSDP thermal regimes environment is expected to be very challenging, and will require all the best drilling and coring development efforts that can be marshalled in order to achieve successful projects.

The worldwide experience of both drilling and coring of boreholes into hot crystalline rocks has demonstrated both the possibilities and problems of deep crustal drilling for scientific purposes. The drilling of $7 \mathrm{~km}$ of borehole in hot crystalline rock at Fenton Hill should serve as a guide for both conceptual and detailed planning of future CSDP projects. The major issues to be considered in such drilling project planning in the areas of casing design, bit selection, coring systems, downhole drilling assemblies, drilling procedures, drilling fluid systems, and on-line problem solving have. been received and recorded.

A list has been developed of the most significant problem areas and needed improvements to successfully approach deep drilling in crystalline rock and extreme temperature environnents expected to be encountered in the deep CSDP themal regimes investigations. These recomendations and judgements were derived from the experience gained at Fenton $\mathrm{Hill}$ and elsewhere, and include suggested approaches toward solutions. 


\section{Acknowledgments}

The Los Alamos Hot Dry Rock Geothermal project is conducted under the auspices of the Geothermal and Hydropower Technology Division of the U.S. Department of Energy. The drilling experiences reported here are the results of the efforts of many of the staff of the HDR project at LOS Alamos. The author wishes to thank those individuals who supported those drilling operations, and to acknowledge the contributions of the many finms who provided the equipment, instruments, services, advice, and supporting personnel. I wish to note with special appreciation and gratitude those companies that supplied innovative and developmental high-temperature-rated hardware and tools for evaluation and use.

\section{References}

Bailey, R. A. and R. L. Smith, Yolcanic Geology of the Jemez Mountains, New Mexico. In: J. W. Hawley (Editor), Guidebook to the Rio Grande Rift in New Mexico and Colorado, N.M. Bur. Mines and Mineral Resources, Circ. 163, $186-196,1978$.

Bailey, R. A., R. L. Snith, and C. S. Ross, Stratigraphic Nomenclature of the Voicanic Rocks in the Jemez Mountains, New Mexico, U.S. Geol. Surv. Butr., 1274-P, 19 pp, 1969.

Campbe11, D. A., C. W. Morris, and R. V. Verity, Geothemal Well Stimuiation Experiments and Evaluation, Soc. Pet. Engrs. Paper No. 10216, 56th Annual Technicat Conference and Exhibit, San Antonio, TX, October 1981. 
Carson, C. and Y. T. Lin, Geothermal Well costs and Their Sensitivity Changes to Drilling and Completion Operations, Proceedings of Int'1. Conference on Geothermal Drilling and Completion Technology, 8-1 to 8-26, January 21-23, 1981.

Continental Scientific Drilling Program, NAS/NRC U.S. Geodynamic Committee, National Academy of Science, Wash. D.C., 1979.

Darring, D. W., "Drill Collar Length is a Major Factor in Vibration Control," Jour. Petroleum Technology, Vol . 36, 637-644, 1984.

Darring, D. W. and J. R. Kelsey, "Balanced Pressure Techniques Applied to Geothermal Drilling," Transactions of the Geothermal Resources Council, Vol. 5, 233-238, 1981.

Dash, Z. V., H. D. Murphy, R. L. Aamodt, R. G. Aguilar, D. H. Brown, D. A. Counce, H. M. Fisher, C. O. Grigsby, H. Heppler, A. W. Laughtin, R. M. Potter, J. W. Tester, P. E., Trujil10, and G. Zyvoloski, Hot Dry Rock Geothemal Reservoir Testing: 1978 to 1980, Jour. of Volcan. and Geotherm. Res., 15, 59-99, 1983.

DiPippo, R., Overview of Worldwide Geothermal Power Development, Geothemal Resources Council Bulletin, Vol. 12, no. 5, 3-9, May 1983.

Fridleifsson, I. B., I. L. Gibson, J. M. Ha11, H. P. Hall, N. I. Johnson, H-V. Christensen, and G. Schenharting, The Iceland Research Drilling Project, Jour. of Geophysical Research, Vo1. 87, No. B8, 6359-6361, August 10, 1982. Goff, F., A. C. Waters (Eds.), Continental Scientific Drilling Program Themal Regimes: Comparative Site Assessment Geology of Five Magma-Hydrothemal Systems, LOS Alamos National Laboratory report LA-8550-OBES, 1980. Heiken, G. and F. Goff (Eds.), Geothermal Energy of Hot Dry Rock, Jour. of Volcan. and Geotherm. Res., Vol. 15, Nos 1-3, January 1983. 
Helmick, C., S. Koczan, and R. Pettitt (Eds.), Planning and Driliing Geothemal Energy Extraction Hole EE-2, LoS Alamos National Laboratory report LA-9302-HDR, April 1982.

Herrick, R. G., Roller Cone/Diamond Drag Core Bit, Soc. Pet. Engrs. Paper No. 7517, 53rd Annual Technical Conference and Exhibit, Houston, TX, 1978. Ioanesyan, Y. R., A. A. Vasilenko, V. P. Matsiyevskiy, and S. L. Simonyouts, "Sovremenuoye Turbinnoye Burehiye," Tekhnitie Press, Kiev, 1977; Translated as "Modern Turbine Drilling," by D. G. Moore and edited by W. C. Cooley, Terraspace Inc., Rockville, MD, 1982.

Knight, K. E., Technology Transfer in the Petroleum Industry, Technology Transfer Society, Int'1. Symposium Proceedings, 179-191, June 20-22, 1983. Larson, V. F., V. B. Robson, and G. N. Foss, Aids to Conventional Drilling Result from Deep Sea Project, World 011, Nov. 1981, 175-198; and Deep Ocean Coring Recent Operational Experience of the Deep Sea Drilling Project, the Soc. Pet. Energy Paper No. 9409 (55th Annual Fall Technical Conference of the SPE of AIME, Sept. 1980).

Laughi in, A. W., The Geothermal System of the Jemez Mountains, New Mexico and Its Exploration. In: L. Rybach and L. J. P. Muffler (Editors), Geothermal Systems: Principles and Case Histories, Wiley, New York, NY, 295-320, 1981.

Laughlin, A. W., A. C. Eddy, R. Laney, and M. J. Aldrich, Geology of the Fenton. H111, New Mexico, Hot Dry Rock Site. Jour. of Volcan. and Geotherm. Res., 15, 21-41, 1983.

Maurer, W. C., Advanced Drilling Techniques, Petroleum Pub. Co., Tulsa, OK, $541-591,1980$. 
Murphy, H. D., J. W. Tester, C. 0. Grigsby, and R. M. Potter, Energy Extraction from Fractured Geothermal Reservoir in Low-Permeability Crystalline Rock, Jour. Geophys. Res., Vo1. 86, B8, 7145-7158, 1981. Neudecker, J. W. and J. C. Rowley, High Temperature Directional Drilling Turbodri11, LoS Alamos National Laboratory report LA-9231-MS, February 1982. Nuckols, E. B., D. Miles, R. Laney, G. Polk, H. Friddle, and G. Simpson, Drilling Fluids and Lost Circulation in Hot Dry Rock Geothermal Wells at Fenton Hill, Proceedings of the International conference on Geothermal Drilling and Completion Technology, 24-1 to 24-22, Jan. 21-23, 1981.

01iver, J., Probing the Structure of the Deep Continental Crust, Science, Vol. 216, 689-695, May 1982.

Osgerby, I. T. and M. Durilla, "Inert Gas Generation Utflizing Diesel Exhaust," Proceedings of the International Conference on Geothermal Driliting and Completion Technology, Albuquerque, MM, PP. 29-1 to 29-20, January 21-23, 1981.

Pettitt, R. A. and R. S. Carden, Sidetracking Experiences in Hot Granite Wellbores, Geothermal Resources Council Transactions, Vol. 5, 267-270, October 1981.

Pettitt, R. A., R. Laney, D. George, and G. Clemens, Evolution of a Hybrid Roller Cone/POC Core Bit, Geothemal Resources Council Transactions, Vol. 4, 305-308, 1980 .

Potter, R. M., Heat flow of the Jemez Plateau (Abstr.), EOS, Trans. An. Geophys. Union, 54, 1214, 1973.

Reiter, M., C. Weidman, C. L. Edwards, and H. Hartman, Subsurface Temperature Data in Jemez Mountains, New Mexico, N.M. Bur. Mines Miner. Resour., Circ., 151, 1-15, 1976. 
Rezanov, I. A., U7tra-Deep Drilling, Nauta (Science) Publishing, 160 pgs., Moscow, 1981 (avallable translation DOE-tr-252).

Rowley, J. C., Rock Melting Applied to Excavation and Tunneling, 1974. In: Advances in Rock Mechanics, Reports of Current Research, Vol. 2, Part B, Proceedings of 3rd International Society of Rock Mechanics, pp. 1447-1453, Denver, Co, 1974.

Rowley, J. C. and R. S. Carden, Drilling of Hot Dry Rock Geothermal Energy Extraction Well EE-3, Los Alamos National Laboratory report LA-9512-HDR, August 1982.

Rowley, J. C. and J. W. Hatkins, Tour of Russian 0il Field Technology, Soc. Pet. Engrs. Paper No. 6718, 52nd Annual Fall Technical Conference and Exhibit, Denver, CO, Oct. 9-12, 1977.

Snith, H. T. U., Tertiary Geology of the Abiquiu Quadrangle, New Mexico, Jour. Geol., 46, 933-965, 1938.

Smith, M. C., A History of Hot Dry Rock Geothemal Energy Systems, 1983, Jour. of Volcan. and Geotherm. Res., 15, 1-20, 1983. 
Table I. Sumary Descriptions of the Fenton Hill Deep Boreholes

\begin{tabular}{|c|c|c|c|c|c|}
\hline Designation & $\begin{array}{c}\text { Date } \\
\text { Drilling } \\
\text { Completed }\end{array}$ & $\begin{array}{l}\text { Drilled } \\
\text { Depth } \\
\text { (m) }\end{array}$ & $\begin{array}{l}\text { Bottomhole } \\
\text { Temperature } \\
\left({ }^{\circ} \mathrm{C}\right)\end{array}$ & \multicolumn{2}{|c|}{ Purpose/Results } \\
\hline GT-1* & 6/1972 & 785 & 100.4 & $\begin{array}{l}\text { - Small diameter } \\
\text { exploration, } 143 \mathrm{~m} \\
\text { Precambrian core, } \\
\text { data, volcanic and } \\
\text { sedimentary sectio }\end{array}$ & drilling \\
\hline GT-2 & $10 / 1974$ & 2928 & 197 & $\begin{array}{l}\text { - Test conductive } \\
\text { gradient, core, } \\
\text { and test equip- } \\
\text { ment. }\end{array}$ & $\begin{array}{l}\text { Developed } \\
\text { first HDR }\end{array}$ \\
\hline$E E-1 * \star$ & $10 / 1975$ & 3065 & 200 & $\begin{array}{l}\text { - Energy produc- } \\
\text { ing, directional } \\
\text { drilling. }\end{array}$ & system \\
\hline$E E-2$ & $5 / 1980$ & 4660 & 320 & $\begin{array}{l}\text { - Injection, } \\
\text { core below } \\
3 \mathrm{~km} \text {. }\end{array}$ & $\begin{array}{l}\text { Drilled as } \\
\text { prototype } \\
\text { HDR well }\end{array}$ \\
\hline$E E-3$ & $8 / 1981$ & 4400 & 280 & - Production & $\begin{array}{l}\text { inclined } \\
35^{\circ} \text { to } \\
\text { vertical, } \\
\text { current } \\
\text { fractional } \\
\text { operations }\end{array}$ \\
\hline
\end{tabular}

* Granite Test Hole No. 1.

** Energy Extraction Hole No. 1. 
Table 11. Comparison of diamond core recovery and intial test of hybrid core bit. (During $24.5 \mathrm{~cm}$ (9-5/8 in.) redrill of GT-2 borehole.)

\begin{tabular}{|c|c|c|c|c|c|c|}
\hline & $\begin{array}{l}\text { Date } \\
(1977)\end{array}$ & $\begin{array}{l}\text { Cored Interyal } \\
\text { Depth } \\
{[m(f t)]}\end{array}$ & $\begin{array}{l}\text { Recovery } \\
\text { (s) }\end{array}$ & $\begin{array}{l}\text { Bit } \\
\text { Type }\end{array}$ & Core Bit Size & Remarks \\
\hline & May 9 & 2799.3 & 0 & D & $\begin{array}{l}24.5-\mathrm{cm} \mathrm{o.d.} \mathrm{by} \\
11.4-\mathrm{cm} 1 . d . \\
(9-5 / 8 \text { by } \\
4-1 / 2 \mathrm{in.})\end{array}$ & $\begin{array}{l}\text { Junk basket run first, but no reaming bit run. Experienced } \\
\text { difficulty getting past kick-off point at } 2482.3 \mathrm{~m}(8144 \mathrm{tt}) \text {. } \\
\text { Reamed to bottom with coring bit; bit bady worn on gauge } \\
\text { (outside) surfaces. Probably no core cut. }\end{array}$ \\
\hline 2672.8 & May 29 & $\begin{array}{c}2672 ; 8-2674.0 \\
\cdot\end{array}$ & 52 & D & $\begin{array}{l}21.6-\mathrm{cm} 0 . d \text {. by } \\
11.4-\mathrm{cm} 1 . d \text {. } \\
(8-1 / 2 \text { by } \\
4-1 / 2 \text { in. })\end{array}$ & $\begin{array}{l}\text { Biotite Granodiorite. Previous drilling was } 9 \mathrm{~m}(30 \mathrm{ft}) \text { of } \\
\text { straight hole cut with } 24.5-\mathrm{cm}(9-5 / 8-1 \mathrm{n} .) \text { bit; hit tracture zone } \\
\text { at } 2672.6 \mathrm{~m}(8769 \mathrm{ft}) \text {. Core showed three fracture planes, two } \\
\text { still sealed with calcite and one reopened. }\end{array}$ \\
\hline & June 9 & $2710.9-2712.1$ & $\mathbf{0}$ & $\mathbf{0}$ & $\begin{array}{l}21.6-\mathrm{cm} \text { o.d. by } \\
11.4-\mathrm{cm} \text { i.d. } \\
(8-1 / 2 \text { by } \\
4-1 / 2 \text { in. })\end{array}$ & $\begin{array}{l}\text { Previous } 18.3 \mathrm{~m}(60 \mathrm{ft}) \text { reamed with rerun } 24.5-\mathrm{cm}(9-5 / 8-i n .) \\
\text { bit, plus } 4.6 \mathrm{~m}(15 \mathrm{ft}) \text { new hole. Supposedly cored } 1.2 \mathrm{~m}(4 \mathrm{ft}) \\
\text { in } 4 \mathrm{~h} \text {. Core bit showed extreme wear on cutting surface, deep } \\
\text { into matrix metal. Diagnosis: loose pieces of rock roliing } \\
\text { around udder bit, no core cut. }\end{array}$ \\
\hline & June 15 & $2712.7(8900)$ & $\mathbf{0}$ & D & $\begin{array}{l}24.5-\mathrm{cm} \text { o.d. by } \\
14.0-\mathrm{cm} 1 . d \text {. } \\
(9-5 / 8 \text { by } \\
5-1 / 2 \mathrm{in.})\end{array}$ & $\begin{array}{l}\text { Reamed hole to bottom with new } 24.5-\mathrm{cm}(9-5 / 8-i n \text {. bit and junk } \\
\text { basket. Could only get core bit down to within } 12.8 \mathrm{~m}(42 \mathrm{ft}) \text { of } \\
\text { bottom. Gauge diamonds of core bit completely worn off. } \\
\text {. }\end{array}$ \\
\hline & June 18 & $\begin{array}{c}2712.7-2713.3 \\
(8900-8902)\end{array}$ & $\mathbf{0}$ & D & $\begin{array}{l}21.6-\mathrm{cm} \text { o.d. by } \\
14.0-\mathrm{cm} \text { i.d. } \\
(8-1 / 2 \text { by } \\
5-1 / 2 \text { in.) }\end{array}$ & Core bit was worn in same pattern as June 9; same diagnosis. \\
\hline & June 19 & $\begin{array}{c}2713.3-2714.9 \\
(8902-8907)^{\circ}\end{array}$ & 89 & H & $\begin{array}{l}20.0-\mathrm{cm} 0 . d \text {. by } \\
7.5-\mathrm{cm} \text { i.d. } \\
(7-7 / 8 \text { by } 3 \text { in. })\end{array}$ & $\begin{array}{l}\text { Biotite Granodiorite. Penetration rate } 0.6 \mathrm{~m} / \mathrm{h}(\mathrm{c} \mathrm{ft} / \mathrm{h}) \text {. Bit } \\
\text { was retrieved with three studs broken off and chisel teeth worn } \\
\text { smooth. Core contained several distinct fracture surfaces, with } \\
\text { possibie evidence of pumping flow. }\end{array}$ \\
\hline
\end{tabular}

D - Conventional dianond.

H - Hybrid, combined polycrystalline diamond compact (PDC) and chisel-tooth, tungsten carbide insert, roller cone. 
Figare/Table Captions

Fig. 1 Location map of the Fenton Hill, New Mexico, Hot Dry Rock Geothermal Site, $32 \mathrm{~km}$ west of the Los Alamos National Laboratory on the western flank of the Valles Caldera. Two deep borehole pairs (GT-2 and EE-1; EE-2 and EE-3) penetrate to $3 \mathrm{~km}$ and $4.4 \mathrm{~km}$ depth in the hot, crystalline crust.

Fig. 2 Geologic map of Jemez Mountains (from Bailey and Smith, 1978 and M. C. Smith, 1983) indicating exploration drilling. Small and large circles locate shallow and deeper heat flow holes. Squares are crystalline basement rock test holes GT-1 and GT-2.

Fig. 3 (a) Temperature profile and (b) generalized geologic section at Fenton Hill, with well configurations indicated. Triangular flags indicate casing depths (set points) and diameters as shown.

Fig. 4 Photograph of Fenton Hill site (1982) showing work towers over GT-2, $E E-1$, and EE-2 boreholes. Such towers can provide for post-drilling logging, and sampling operations. A workover rig is set up over the EE-3 we11 bore.

Fig. 5 Schematic of HDR parallel fracture system reservoir to be created in open-hole, $35^{\circ}$ inclined sections of EE-2 and EE-3 wellbores.

Fig. 6 Directional drilled configuration of the EE-2/EE-3 boreholes, (a) plan view, (b) vertical section projected into east-west plane. The accuracy of the trajectory surveys and relative position precision of the wellbores indicates the potential for measurements between boreholes in future deep crustal drilling projects. 
Fig. 7 Drilling history, solid curve, of (a) EE-2 and (b) EE-3 boreholes. Cost of circulating fluid chemical additives, dashed curve, is also shown (converted to 1979 dollars). A major mechanical problem is indicated for each borehole. The temperature profile at Fenton Hill is indicated in (a) and the depths shown are measured along the wellbore.

Fig. 8 Four-cone, tungsten carbide insert core bit developed by Deep Sea Drilling Project for sea bed sedimentary rock coring. Bit has 25.1 cm $\left(9-7 / 8-i n_{.}\right)$diameter and cuts a $7.0 \mathrm{~cm}$. $\left(2-7 / 8-i_{\text {. }}\right)$ diameter core.

Fig. 9 Hybrid core bit with both four-cone and polycrystalline diamond compact (PDC) drag cutting structures. Developed for the Los Alamos HDR Geothermal Project for coring of deep crystalline rocks. Before use, (b) after first trial run (Table II). Bit has $20.0 \mathrm{~cm}$ (7-7/8 in.) diameter and cuts a $7.5 \mathrm{~cm}(3-\mathrm{in.})$ core.

Fig. 10 Special $22.2 \mathrm{~cm}(8-3 / 4-i n$.$) diameter rock bit used for drilling in$ deep, hot crustal crystalline rocks. Design features tungsten carbide insert (TCI) and gauge pad wear protection; and open, air-cooled type bearings.

Fig. 11 (a) Near bit roller reamer and (b) blade stabilizer after extreme abrasive wear. The roller reamer and stabilizer configuration are preferred in abrasive hard rocks. 
Fig. 12 Sketches of the Soviet advance open hole drilling strategy for ultra-deep boreholes in stable formations. (a) Initial borehole with $24.5-\mathrm{cm}\left(9-5 / 8-i n_{.}\right)$diameter uncemented protective casing string set and drilling below with turbodrill and $21.4 \mathrm{~cm}$ $(8-1 / 2-i n$.$) bit. (b) When wellbore sloughing is encountered remove$ protective string, ream at $39.4 \mathrm{~cm}(15-1 / 2-i n$.$) , and set and$ cement-in a $32.5 \mathrm{~cm}(12-3 / 4$ in.) casing. (c) Install a $24.5-\mathrm{cm}$ (9-5/8-in.) protective casing and continue drilling below. This technique is apparently applicable to most crystalline rocks, and can be a possible general approach to deep crustal drilling. Fenton Hill crystalline rock borehole stability would appear to be sufficient to apply the Soviet method.

Fig. 13 A recommended drilling strategy for CSDP thermal regimes investigations of hydrothermal convection system. (a) Slim hole core to top of hydrothermal reservoir zones of high permeability, (b) drill second borehole through shallow formations previously cored and set casing into the caprock, and core through the permeable zones, possibly using a dual string drill string drill rig, to a depth of about $3 \mathrm{~km}$. (c) The third deep borehole is drilled through the hydrothermal reservoir and a heavy casing is set; possibly use two strings. Then coring proceeds below to the 6-9 km depths.

Fig. 14. Historical drilling cost comparisons for hydrothermal, HDR, and oil and gas wells (adapted from Carson and Lin, 1981). Costs normalized to value of 1979 dollars through use of a $17 \%$ escalation factor. 
Fig. 15 Schematic of use of bar code strips to provide reliable, unique, and automatic identification system for drill pipe sections (joints). Code can be used to calculate stress and estimate fatique life, and integrate inspection data with the result of reduced drill pipe failures.

Fig. 16 (a) Turbocorer concept (b) conceptual design of a hard rock core bit. Adapted from deep sea drilling and HDR experience.

Fig. 17. Sketch of drill stem tester for deep crustal applications. Used to obtain formation fluid samples without contamination by circulating drilling fluid.

Table I Summary descriptions of the Fenton Hill deep boreholes.

Table II Comparison of diamond core recovery and initial test of hybrid core bit. 


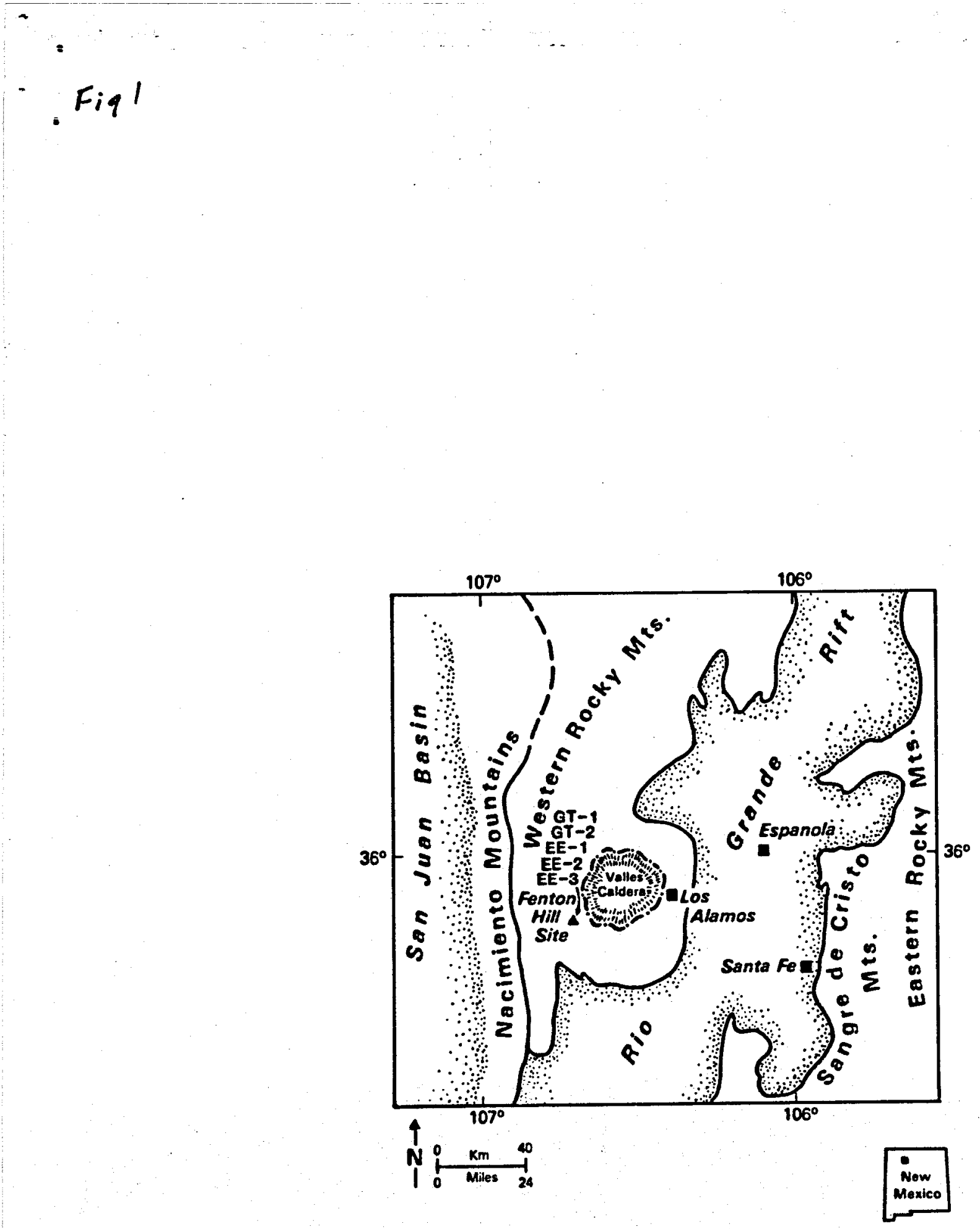




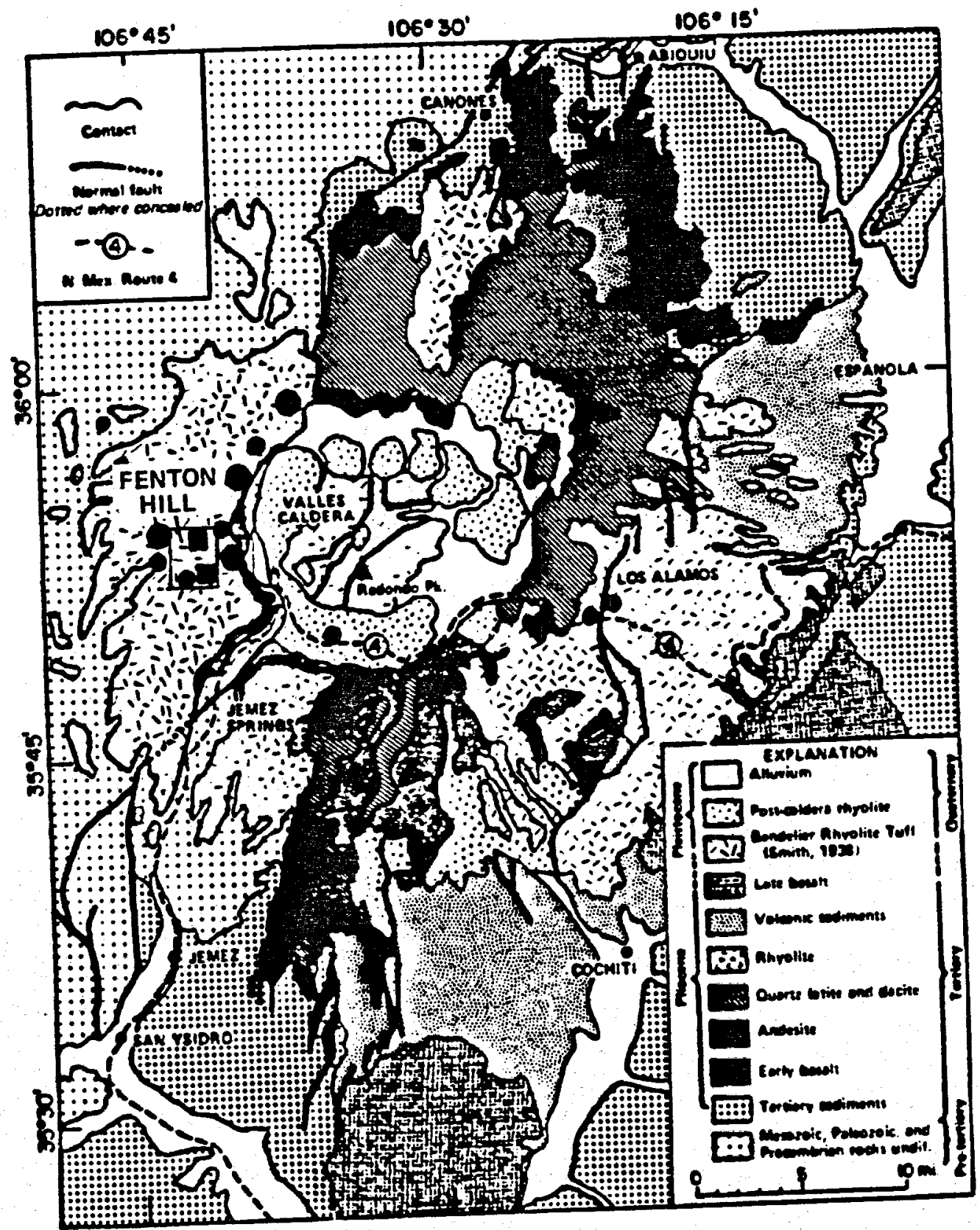


(a)

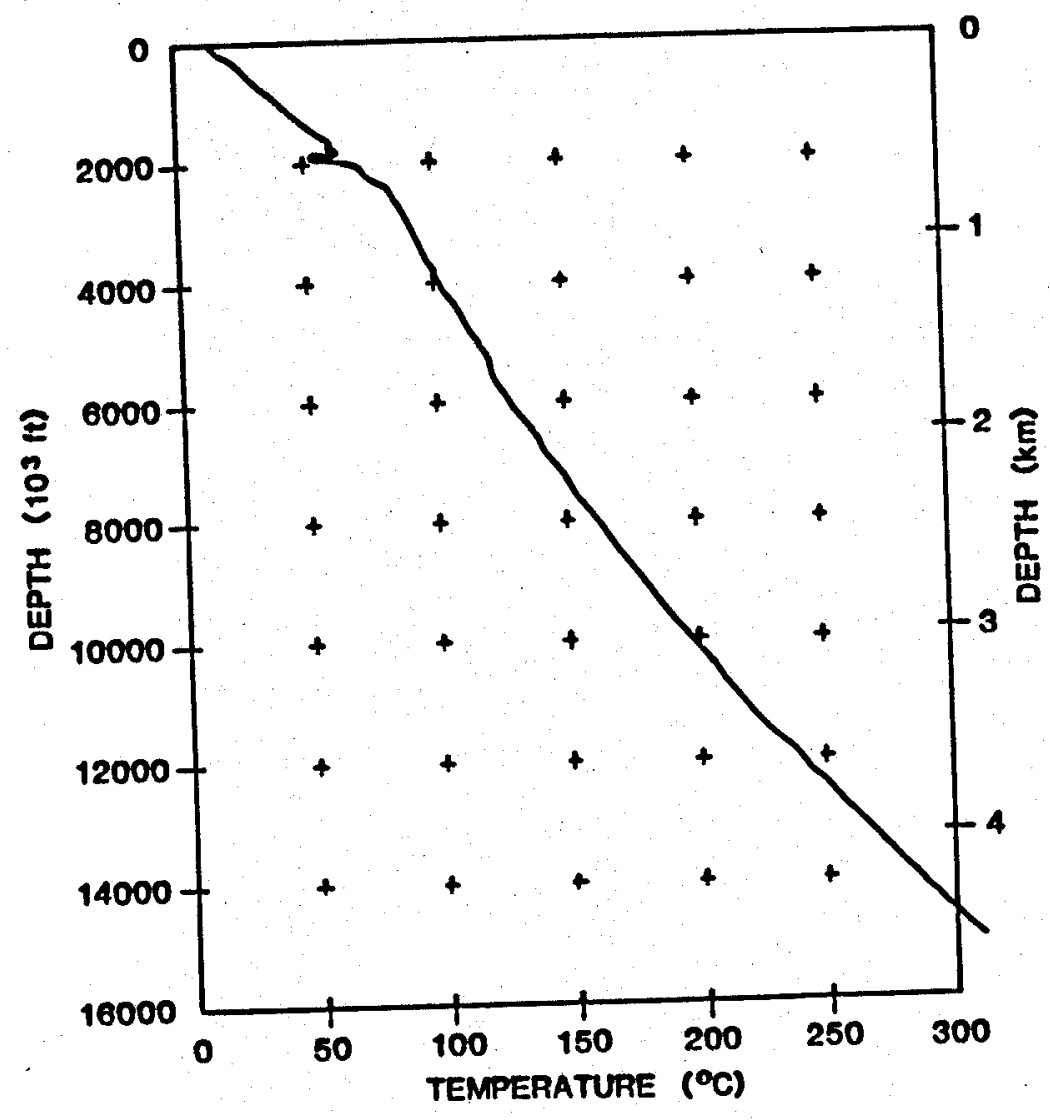

(b)

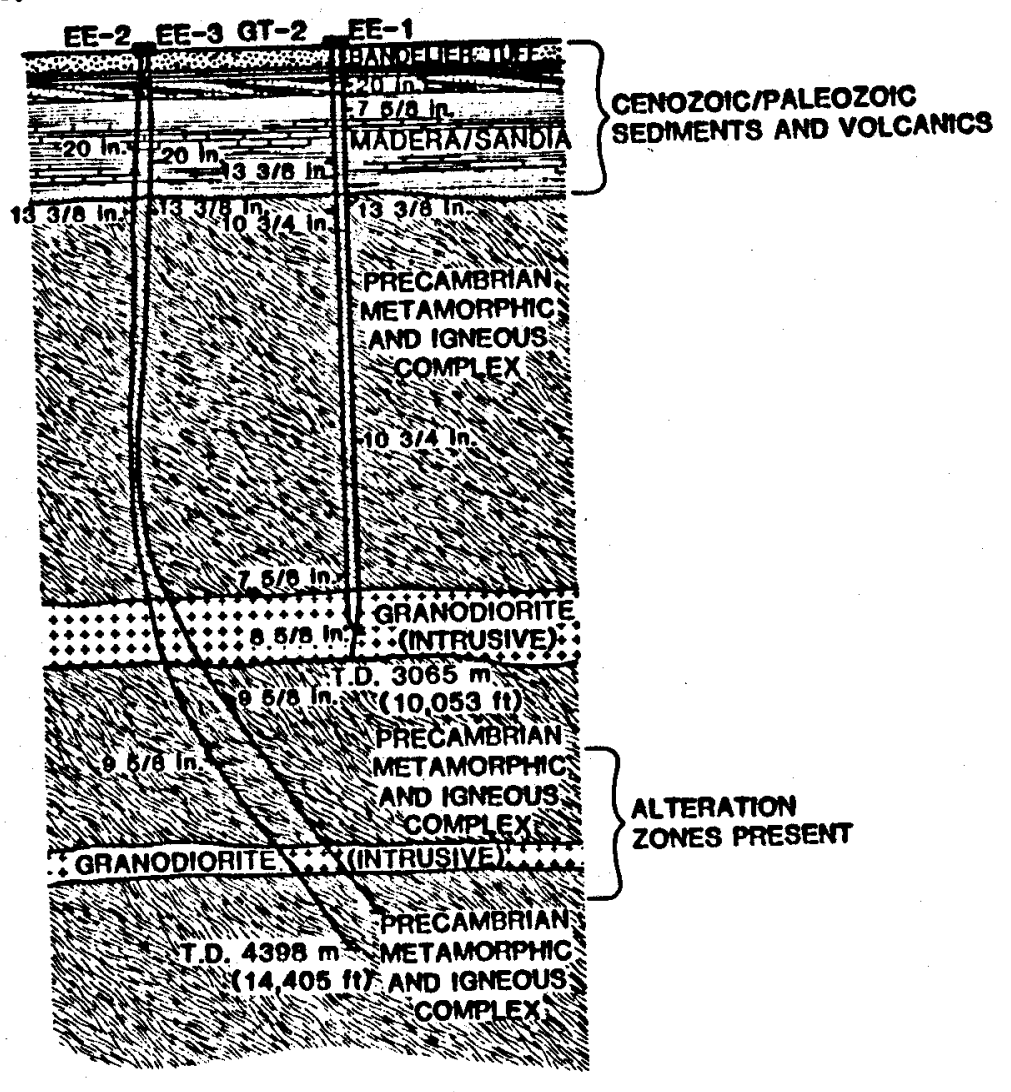




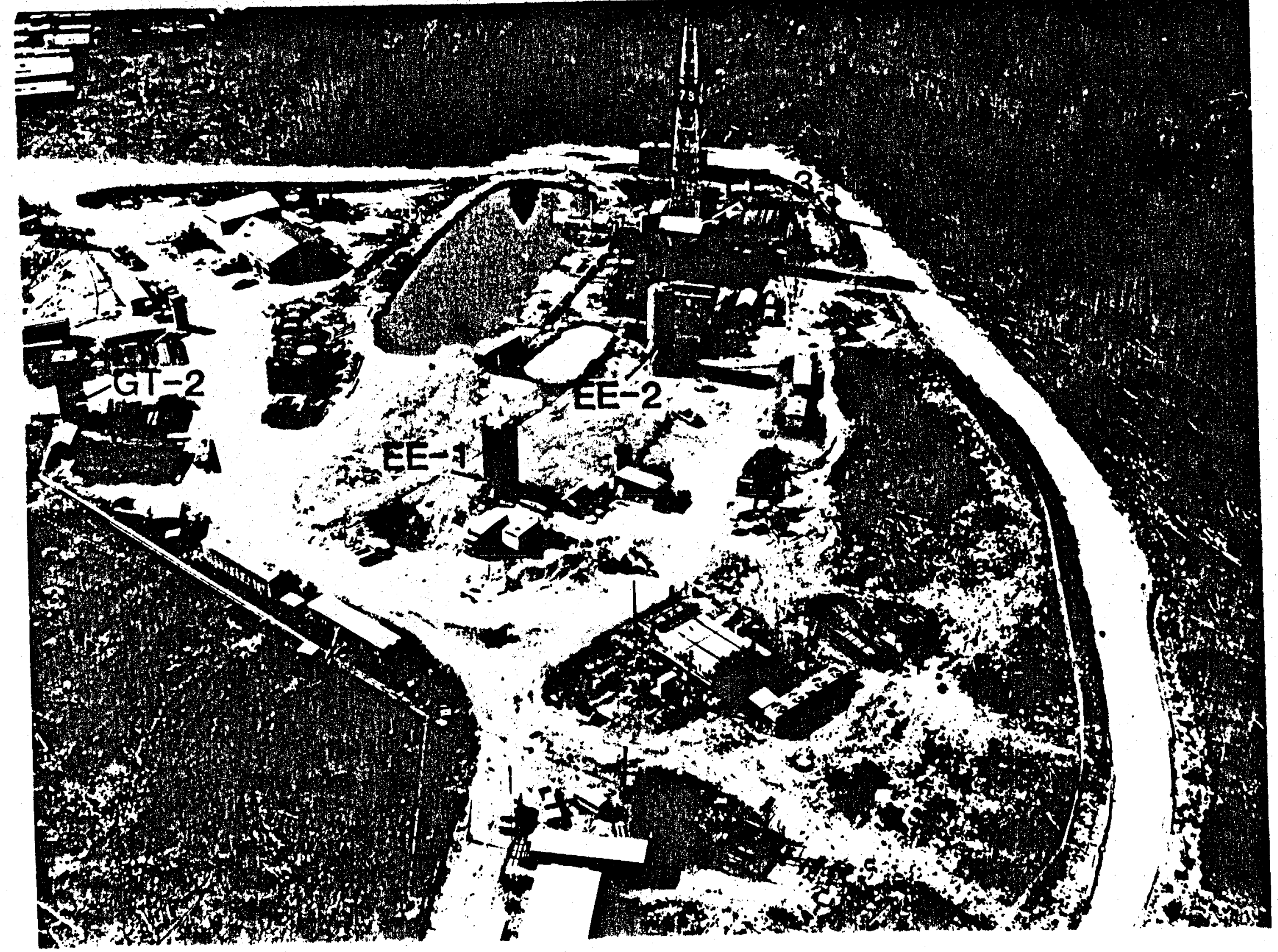


Fiq. 5

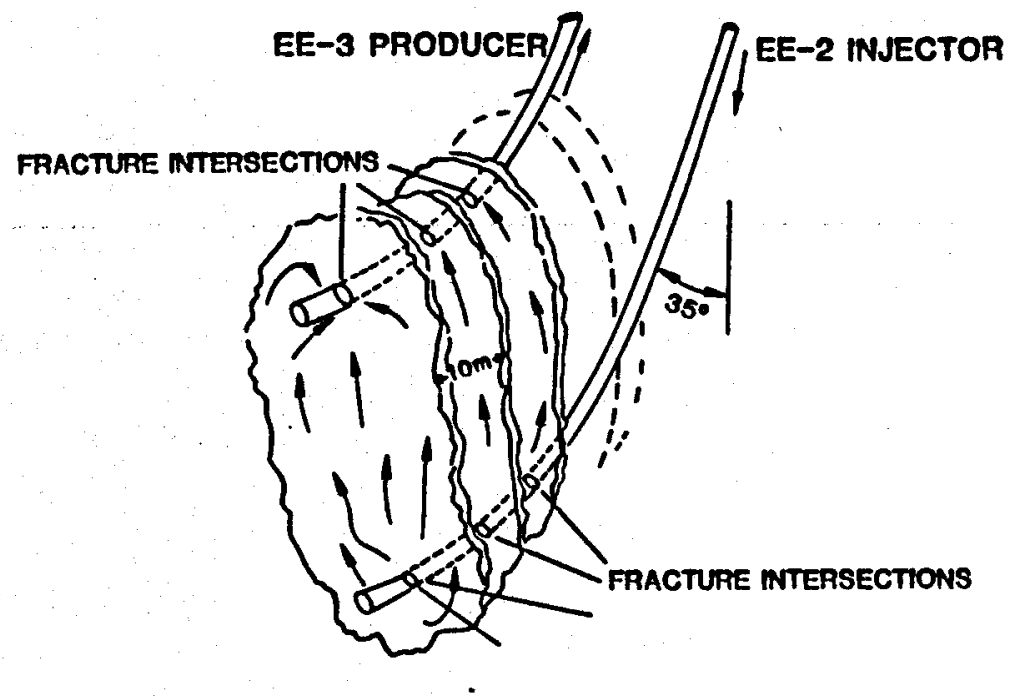


(a) EE-2 DRILLING HISTORY

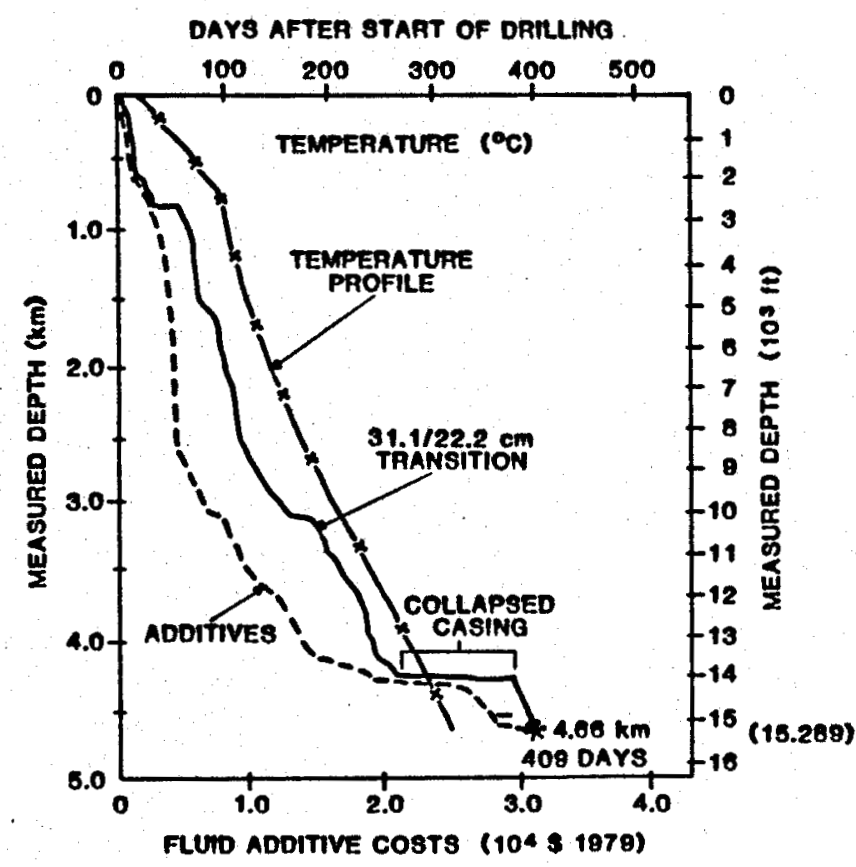

(b) EE-3 DRILLING HISTORY

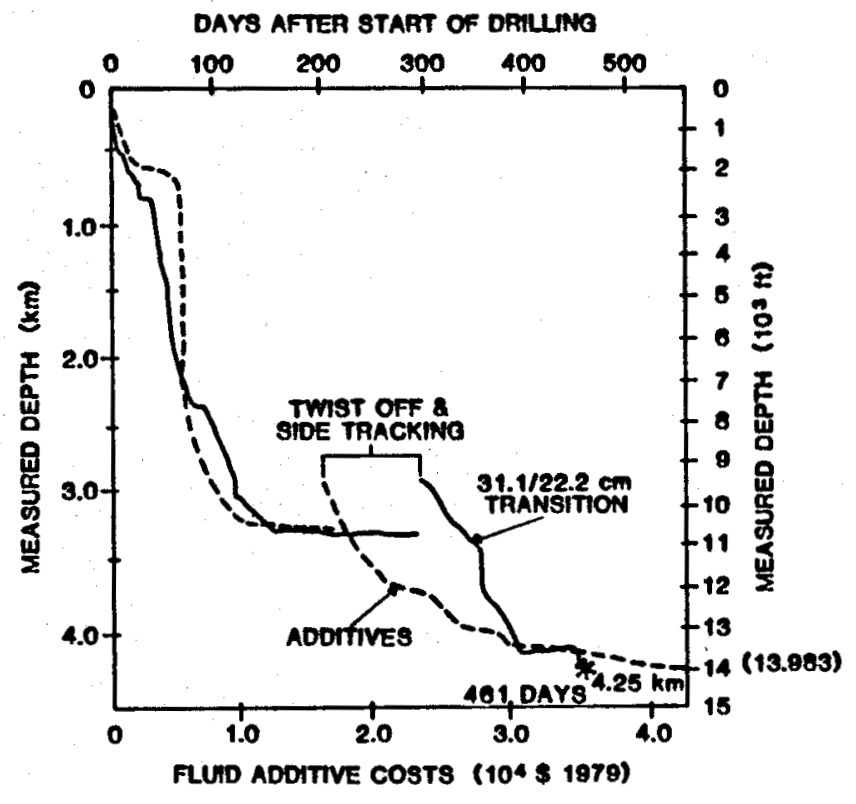




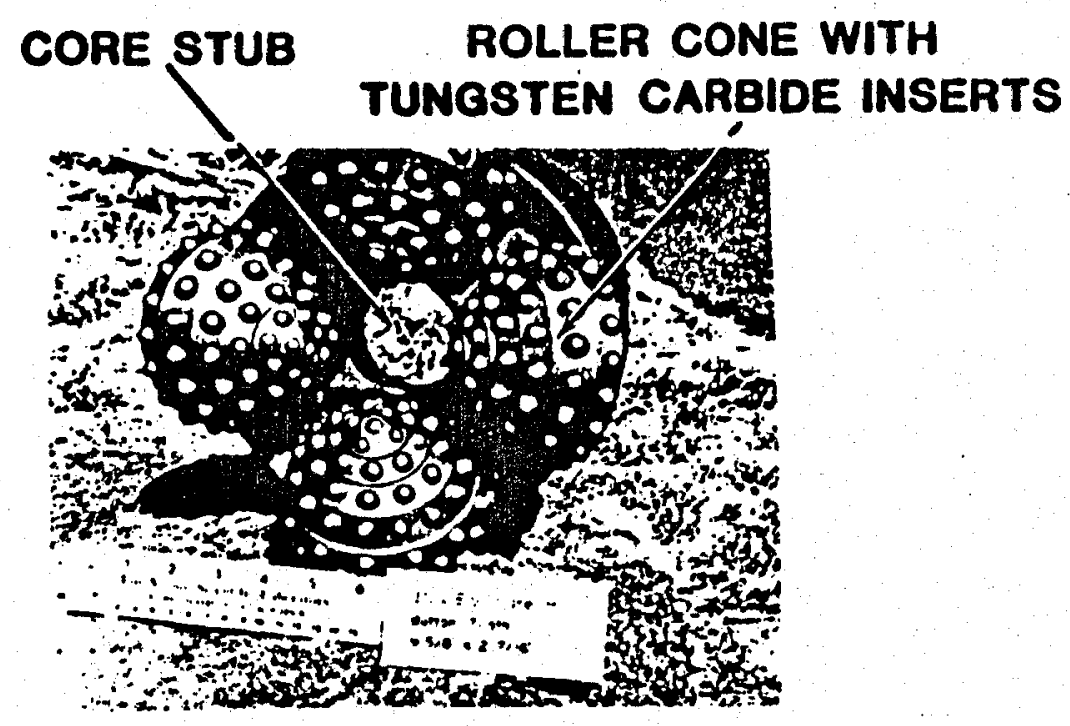

sibly 
Fig. 9

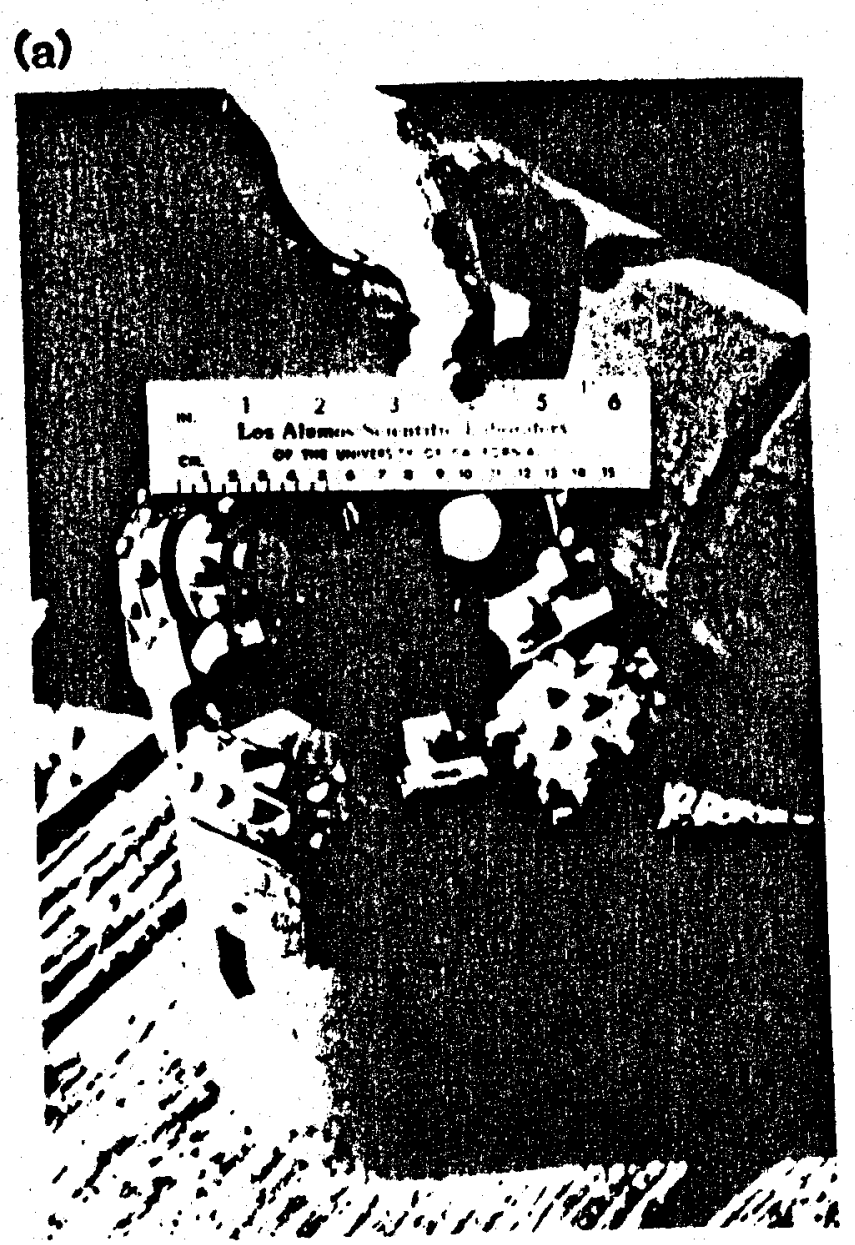

(b)

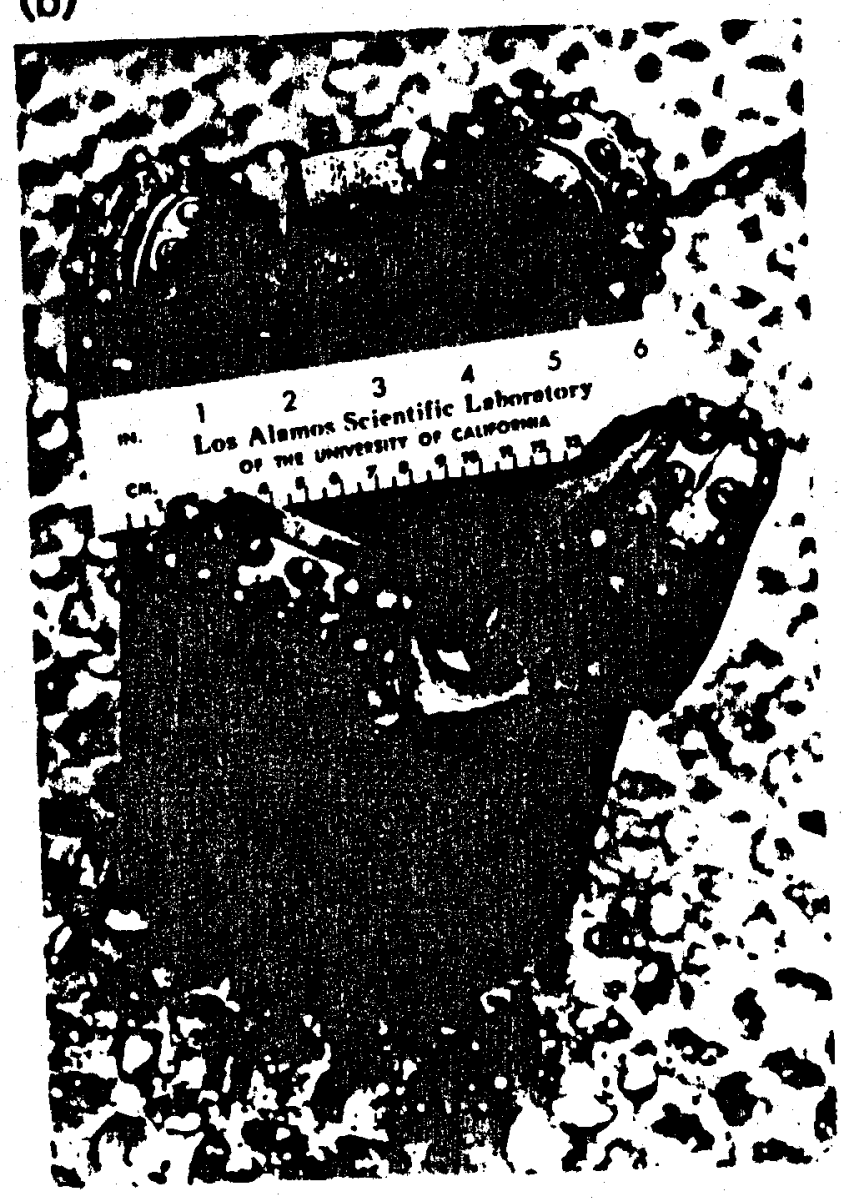




\section{Figlo}

TCI WEAR PROTECTION

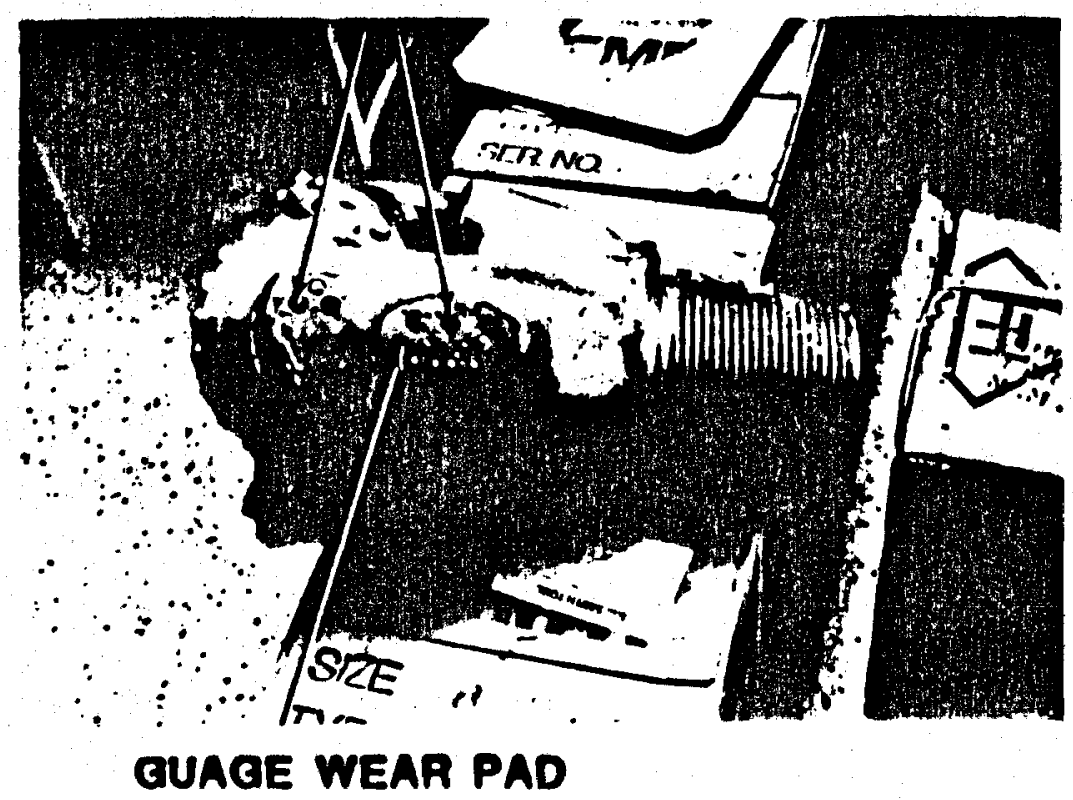



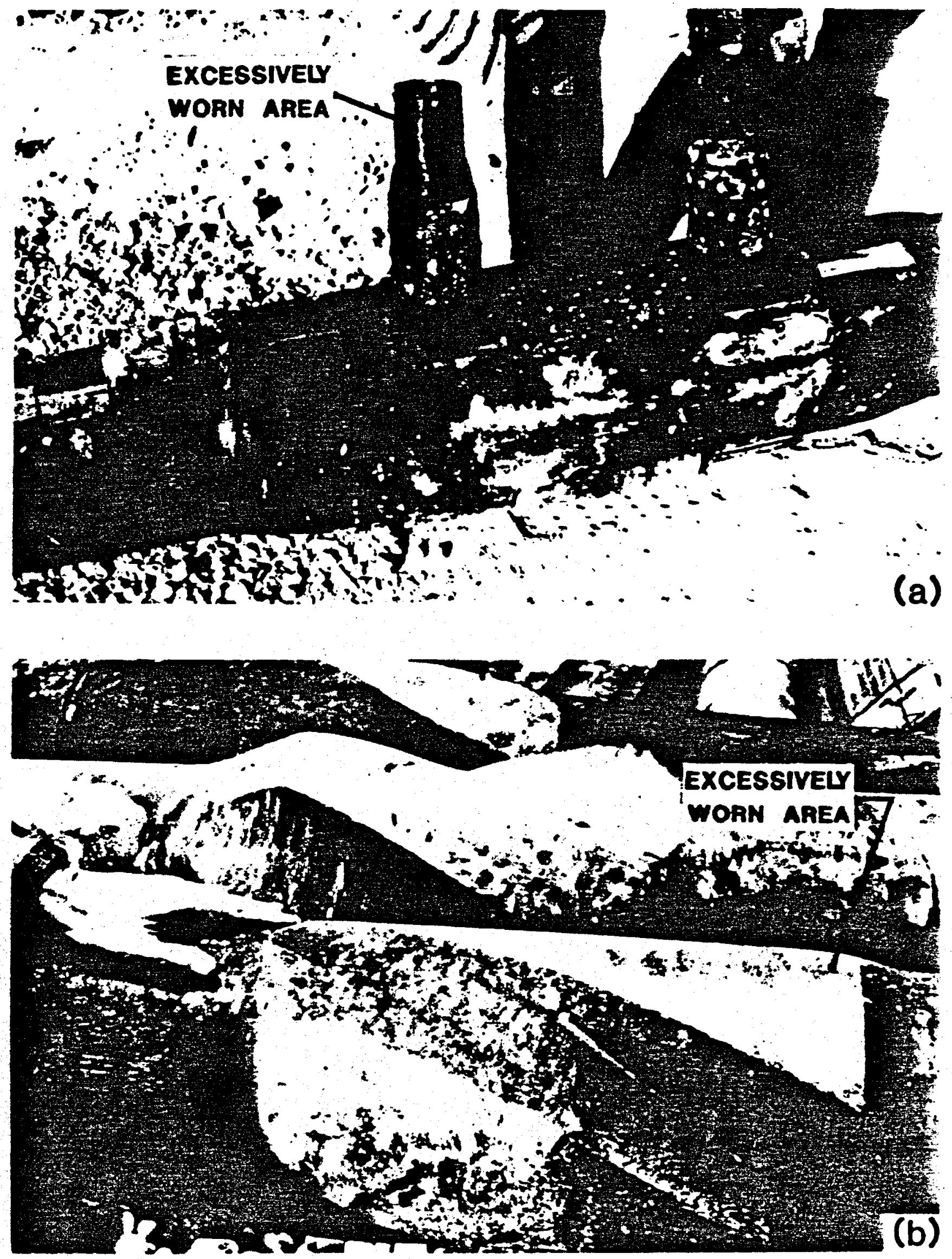
Fiç.12

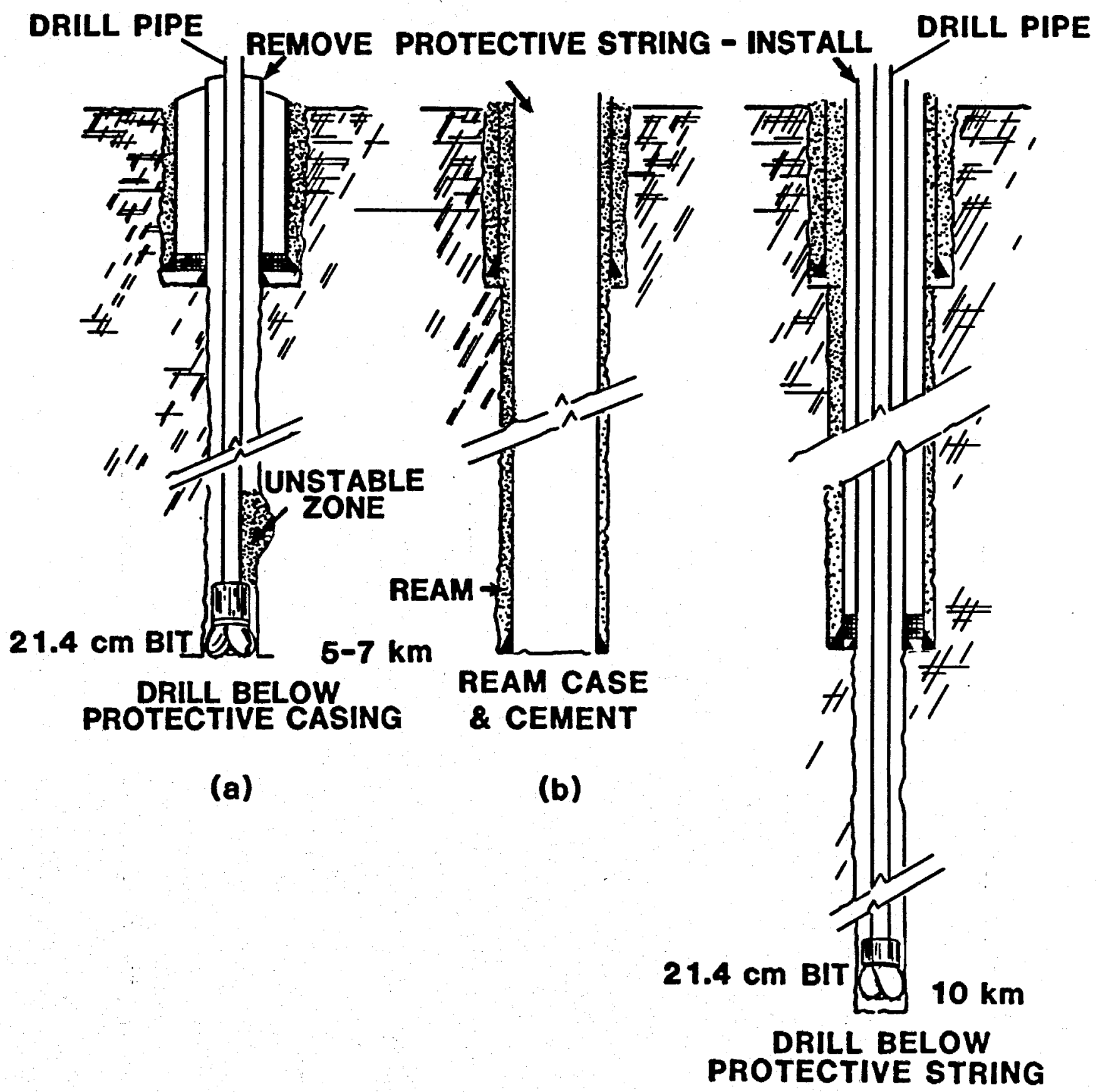

(c) 
Fig. 13

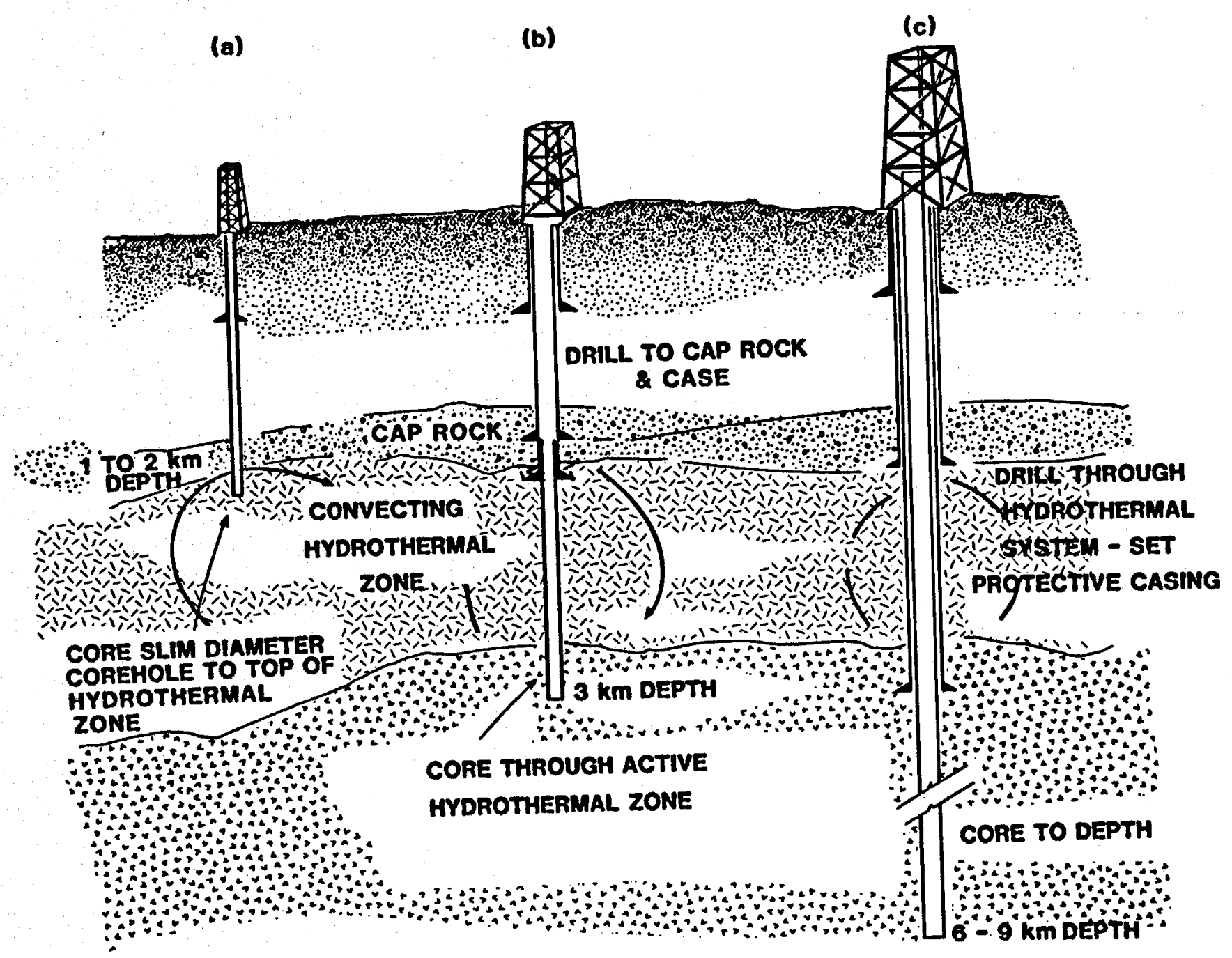


Fig:14

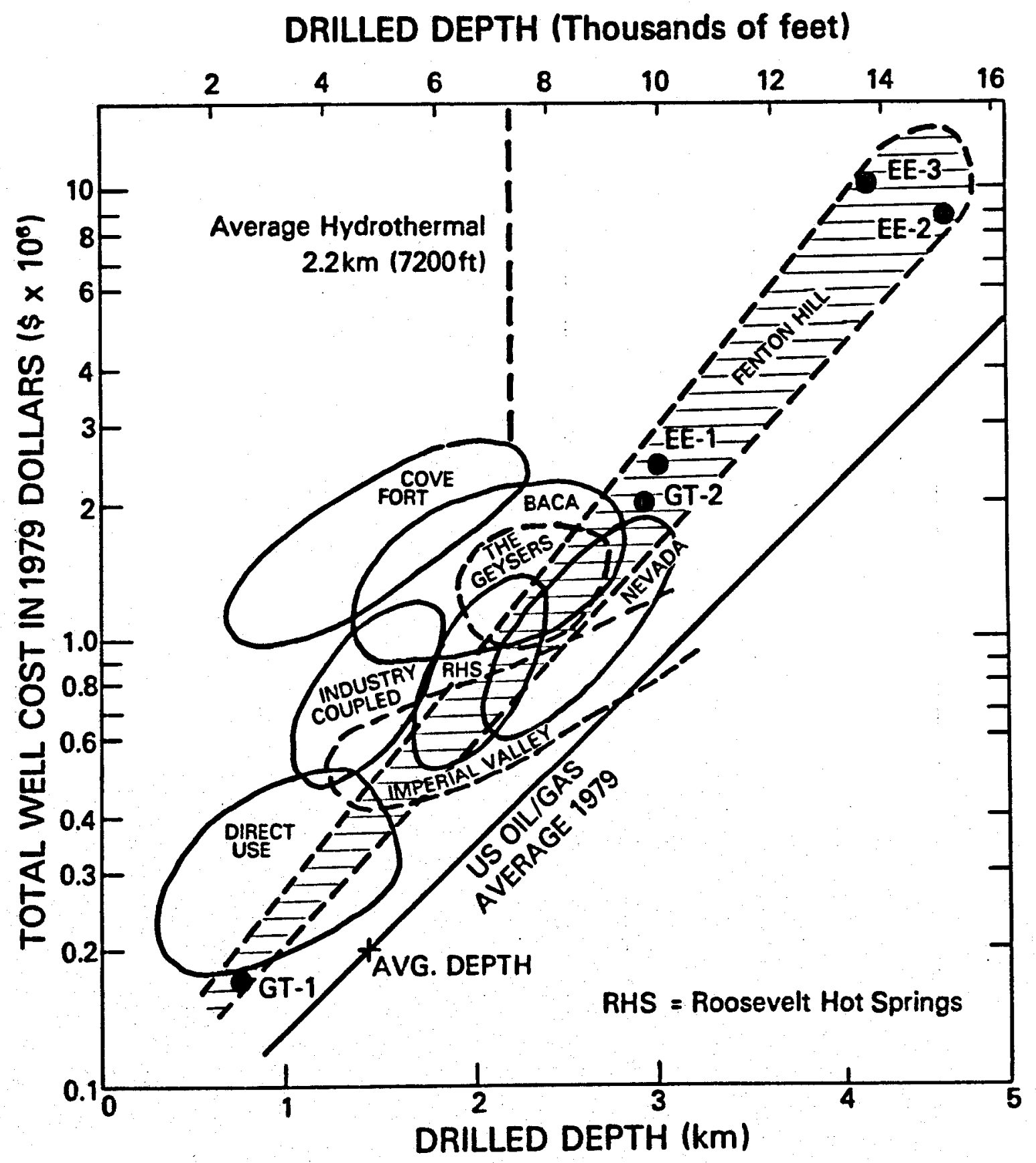


Ficis

IN THE DERRICK
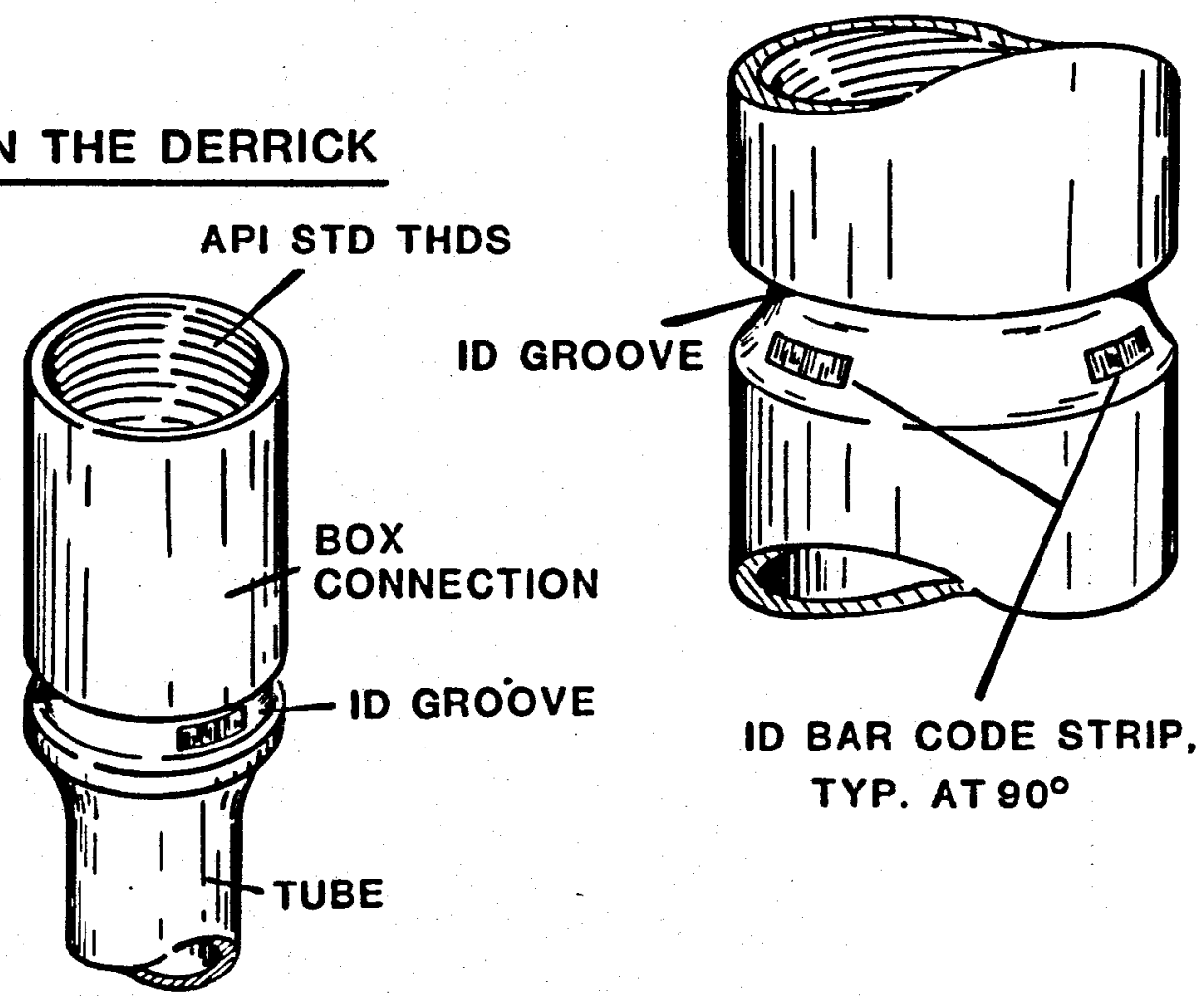

ID BAR CODE STRIP, TYP. AT $90^{\circ}$

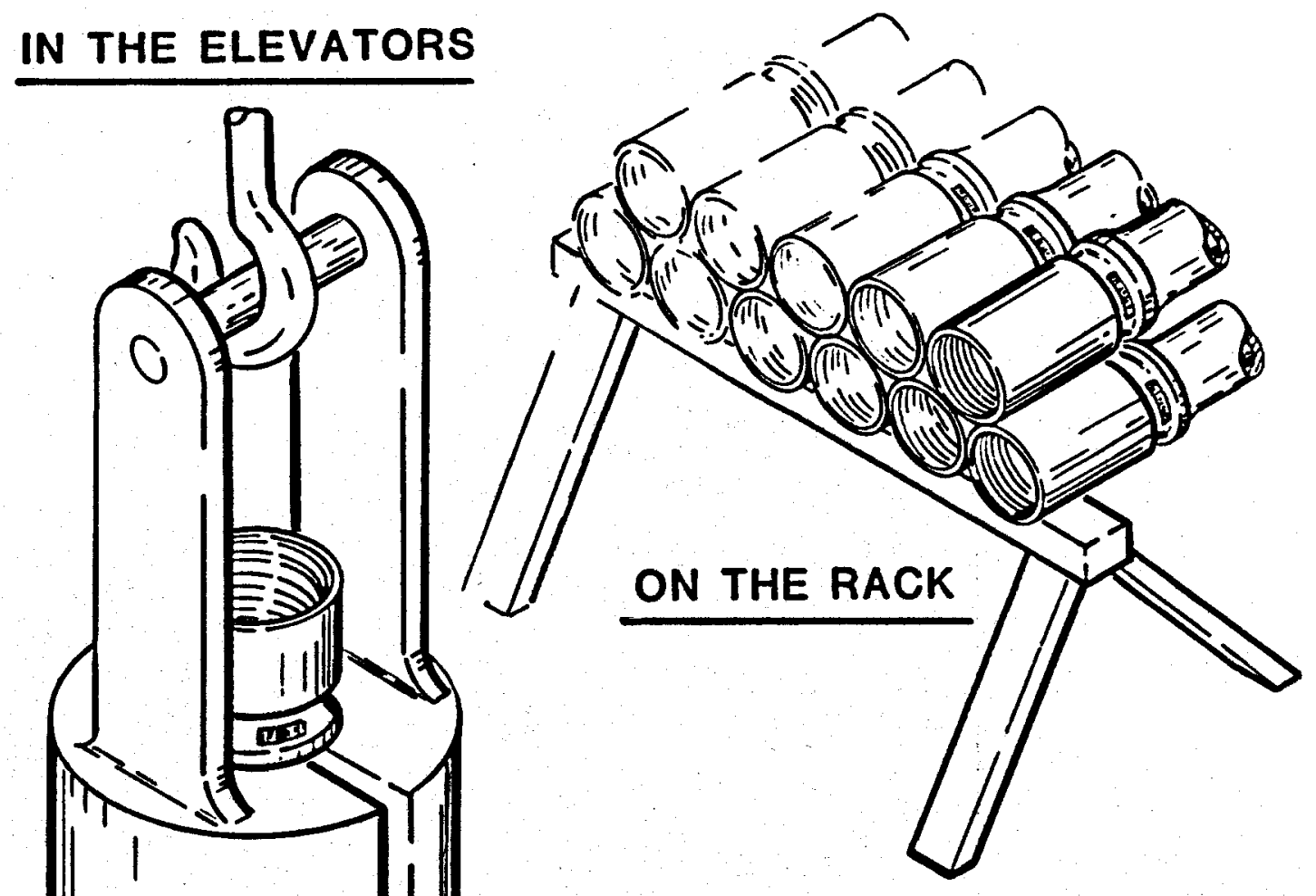

NOTE: MAGNETIC SENSOR CONFIGURATIONS REQUIRED FOR THESE THREE SITUATIONS. 

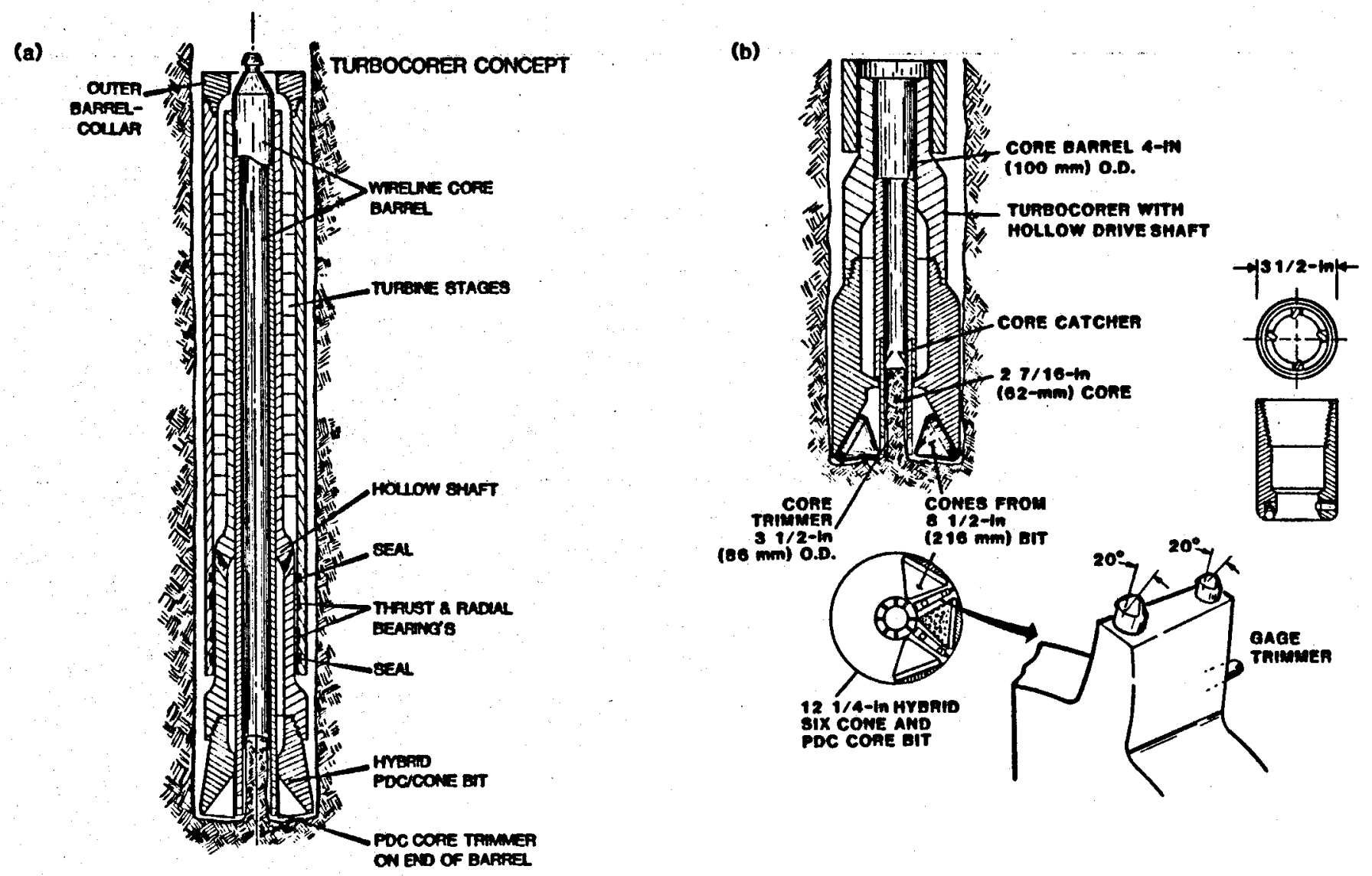
Fig. 17

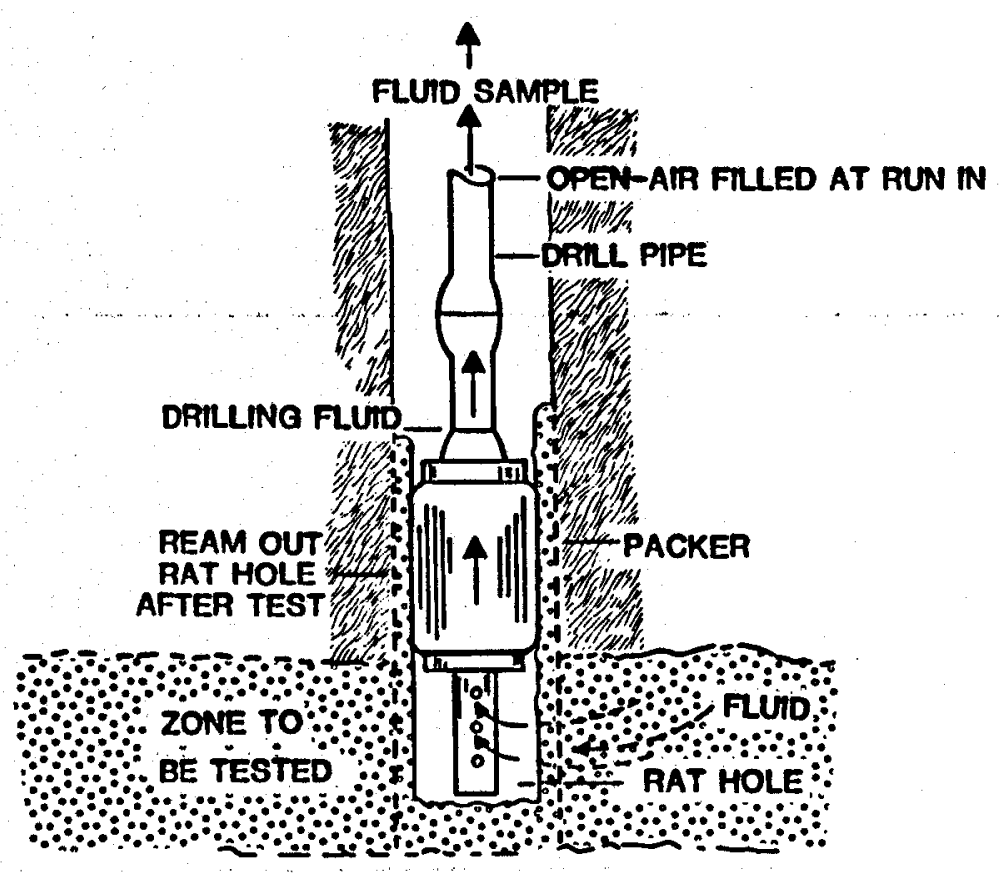

